Späth, T., M.-L. Bai, L. L. Severinghaus and B. A. Walther 2018. Distribution, habitat, and conservation status of the near-threatened Japanese Paradise-Flycatcher (Terpsiphone atrocaudata periophthalmica) on Lanyu, Taiwan. Avian Conservation and Ecology 13(1):7. https://doi.org/10.5751/ ACE-01167-130107

Copyright $(\mathcal{} 2018$ by the author(s). Published here under license by the Resilience Alliance.

Research Paper

\title{
Distribution, habitat, and conservation status of the near-threatened Japanese Paradise-Flycatcher (Terpsiphone atrocaudata periophthalmica) on Lanyu, Taiwan
}

\author{
Thorsten Späth ${ }^{1}$, Mei-Ling Bai ${ }^{2}$, Lucia L. Severinghaus ${ }^{3}$ and Bruno Andreas Walther ${ }^{4}$ \\ ${ }^{1}$ Georg-August-University-Göttingen, Conservation Biology/Workgroup on Endangered Species, Göttingen, Germany, ${ }^{2}$ Formosa \\ Natural History Information Ltd., Taipei, Taiwan, ${ }^{3}$ Biodiversity Research Center, Academia Sinica, Taipei, Taiwan, ${ }^{4}$ Master \\ Program in Global Health and Development, College of Public Health, Taipei Medical University, Taipei, Taiwan
}

\begin{abstract}
The near-threatened Japanese Paradise-Flycatcher (Terpsiphone atrocaudata) consists of three subspecies, one of which, T. a. periophthalmica, has an important population on Lanyu, Taiwan. After briefly reviewing the species' conservation status in its breeding range, we describe our field work in Lanyu during the breeding seasons of 2009 and 2010 . We first established that the territory size of a male flycatcher is around 1.16 hectares. We then visited 224 1-hectare grid cells randomly distributed across Lanyu and established 120 presence grid cells. We then used these presence grid cells and nine environmental data layers to build an ensemble distribution model using the software Maxent. The model showed that the Japanese Paradise-Flycatcher prefers relatively wet forest habitats at elevations of 50-300 m. Using the model, we estimated that the extent of suitable habitat covered approximately $12.0 \mathrm{~km}^{2}$ (or 26\%) of Lanyu's surface area, which could hold approximately 1000 male territories. Forest cover increased between 1948 and 2006 by approximately $7.6 \mathrm{~km}^{2}$ (or 16\%) of Lanyu's surface area, which, all other things being equal, should have resulted in a population increase of around $30 \%$. Given the absence of current threats, the Lanyu population is assumed to be relatively stable. Given this new information and our review of the species' conservation status, we suggest that the species may be down-listed to "least concern." However, if the distinct subspecies T. a. periophthalmica would be elevated to species status or be considered two independent conservation units (one in Lanyu and one in Batanes, Philippines), its conservation status would be much more precarious given it only occurs in five known localities (Lanyu and four islands in Batanes) of limited geographic range, and a population size of approximately 1000 males in Lanyu and an unknown population size in Batanes. Therefore, we conclude that more information is needed about (1) the species' status in Batanes, (2) its migration and wintering grounds, and (3) the taxonomic status of the three subspecies.
\end{abstract}

\section{Répartition, habitat et statut de conservation du Tchitrec du Japon (Terpsiphone atrocaudata periophthalmica), quasi menacé, sur l'île de Lanyu, Taïwan}

RÉSUMÉ. Le Tchitrec du Japon (Terpsiphone atrocaudata) quasi menacé, compte trois sous-espèces dont l'une, T. a. periophthalmica, est bien établie sur l'île de Lanyu, Taïwan. Après une brève revue du statut de conservation de l'espèce dans son aire de nidification, nous décrivons les travaux réalisés sur Lanyu durant les saisons de reproduction de 2009 et 2010. Dans un premier temps, nous avons déterminé que la taille du territoire d'un tchitrec mâle est de 1,16 ha environ. Nous avons ensuite visité 224 unités de grille de 1 ha réparties aléatoirement sur Lanyu, et avons observé que l'espèce était présente dans 120 d'entre elles. Nous avons utilisé les unités de grille avec présence et neuf couches de données relatives à l'environnement pour bâtir un modèle de répartition d'ensemble au moyen du logiciel Maxent. Le modèle a révélé que le Tchitrec du Japon se rencontre plus souvent dans les milieux forestiers relativement humides, à une élévation allant de 50 à $300 \mathrm{~m}$. À partir du modèle, nous avons estimé que les milieux propices couvraient approximativement $12,0 \mathrm{~km}^{2}$ (ou $26 \%$ ) de la superficie de Lanyu, étendue qui pourrait héberger à peu près 1000 mâles territoriaux. Le couvert forestier s'est accru entre 1948 et 2006, d'environ 7,6 km² (ou 16\%) de la superficie de Lanyu, ce qui, toutes choses égales d'ailleurs, laisse entendre que la population pourrait avoir augmenté de l'ordre de $30 \%$. Puisqu'il n'existe pas de menaces actuellement, nous supposons que la population sur Lanyu est relativement stable. À la lumière de cette nouvelle information et de notre revue du statut de conservation de l'espèce, nous proposons que son statut soit abaissé à celui de " préoccupation mineure ». Toutefois, si la sousespèce $T$. a. periophthalmica était élevée au rang d'espèce ou si l'on considérait qu'il existe deux unités de conservation indépendantes (l'une sur Lanyu et l'autre dans la province de Batanes, Philippines), son statut de conservation serait beaucoup plus précaire puisque cette sous-espèce n'est connue pour fréquenter que cinq endroits (Lanyu et quatre îles en Batanes) d'étendue géographique limitée, et que la population n'est que de 1000 mâles environ sur Lanyu et que sa taille est inconnue en Batanes. Nous concluons que plus de recherche doit être faite sur : 1) le statut de l'espèce en Batanes; 2) ses migrations et ses aires d'hivernage; et 3) le niveau taxinomique des trois sous-espèces.

Key Words: breeding population; conservation status; Japanese Paradise-Flycatcher; Maxent; Terpsiphone atrocaudata

Address of Correspondent: Bruno Andreas Walther, Master Program in Global Health and Development, College of Public Health, Taipei Medical University, Taipei, Taiwan, bawalther2009@gmail.com 


\section{INTRODUCTION}

Island bird species and populations are especially threatened by extinction (Johnson and Stattersfield 1990), and habitat destruction and invasive species are the two main causes (Veitch and Clout 2002, Reaser et al. 2007). Therefore, there is a growing focus on the value of conserving island populations as independent conservation units (Kier et al. 2009, Pruett et al. 2017). Because conservation and management of species is dependent on knowledge of a species' distribution, ecology, and population size (Sutherland et al. 2004), an understanding of the main factors determining a species' presence will assist conservation managers in prioritizing actions and increasing the efficacy of any applied strategy (Sutherland et al. 2004). The East Asian region has a large number of island bird species that remain little known and understudied (Collar et al. 2001, Brazil 2009, Ando et al. 2014).

One such species is the near-threatened Japanese ParadiseFlycatcher (Terpsiphone atrocaudata), also known as Black Paradise-Flycatcher. This species has been divided into three subspecies, which breed in mature evergreen broadleaf, deciduous, or mixed forests, and sometimes in plantations up to $1000 \mathrm{~m}$ elevation (Kennedy et al. 2000, Coates et al. 2006, Brazil 2009, Severinghaus et al. 2010, 2017, Jeyarajasingam and Pearson 2012, BirdLife International 2015). The three subspecies are distributed as follows: (1) T. a. atrocaudata in Japan and Korea (according to Ding et al. 2014 and R.-S. Lin, 2016, personal communication, this subspecies does not breed in Taiwan, contra Coates et al. 2006); (2) T. a. illex in Ryukyu Islands (or Nansei Shoto), Japan; (3) T. a. periophthalmica in Lanyu (or Orchid Island), Taiwan, and the Batanes Islands, which includes Batan Island, northern Philippines (Fig. 1; Nuytemans 1998, Kennedy et al. 2000, Coates et al. 2006, Duckworth and Moores 2008, Brazil 2009, Severinghaus et al. 2010, 2017, Jeyarajasingam and Pearson 2012, BirdLife International 2015; Batanes Islands biodiversity survey, unpublishedmanuscript). T. a. periophthalmica is very distinct from the other two subspecies and has been considered a full species by some authors (e.g., McGregor 1907, Alcasid 1965). T. a. atrocaudata is fully migratory, T. a. illex is partially migratory (or perhaps resident), and T. a. periophthalmica in Lanyu is mostly migratory (Nuytemans 1998, Kennedy et al. 2000, Coates et al. 2006, Gonzalez et al. 2008, Brazil 2009, Severinghaus et al. 2010, 2017, BirdLife International 2015; J. C. T. Gonzalez, 2016, personal communication; G.-Q. Wang, personal communication; Appendix 1). Whether the Batanes population of $T . a$. periophthalmica is partially or completely migratory or even completely resident remains an open question (J. C. T. Gonzalez, 2016, personal communication). The migratory populations winter in forests and mangroves up to $700 \mathrm{~m}$ elevation in the northern Philippines, southern Thailand, peninsular Malaysia, Singapore, and Sumatra (Nuytemans 1998, Kennedy et al. 2000, Coates et al. 2006, Oliveros et al. 2008, Brazil 2009, Jeyarajasingam and Pearson 2012, BirdLife International 2015).

The near-threatened conservation status of the Japanese Paradise-Flycatcher appears to be based mostly on older Japanese studies (Appendix 1) and an assumed habitat loss on the wintering grounds (BirdLife International 2015). However, BirdLife International (2015) proposed that more studies and careful monitoring are needed in order to (1) determine its current distribution and abundance on both the breeding and wintering range and (2) increase knowledge of its habitat requirements.
Fig. 1. Distributions of the three subspecies of the Japanese Paradise-Flycatcher (Terpsiphone atrocaudata): (green) T. $a$. atrocaudata in Japan, South and North Korea; (blue) T. a. illex in Ryukyu Islands, Japan; (dark red) T. a. periophthalmica in Lanyu Island, Taiwan, and Batanes Islands, Philippines.

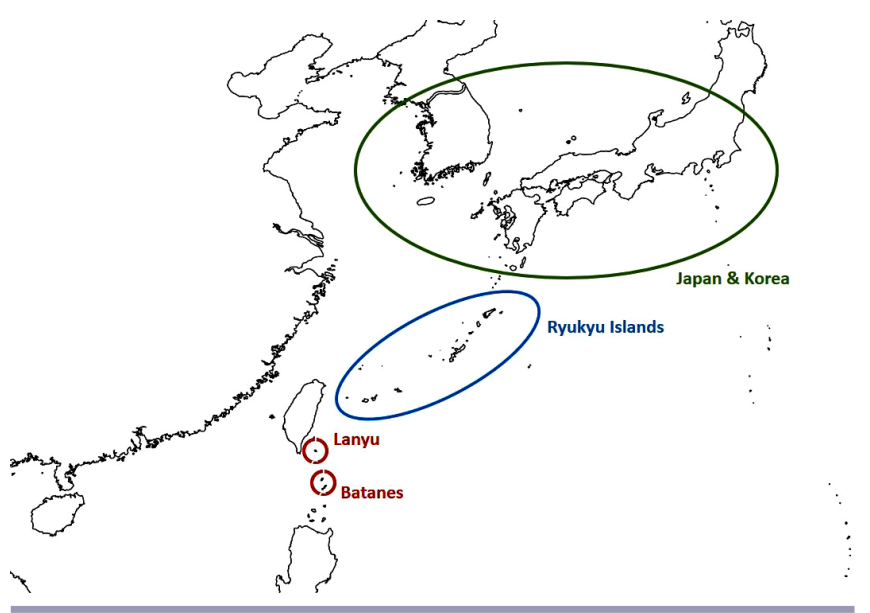

To further improve our knowledge of this species, we (1) assessed the species' current conservation status using the available literature, (2) used the species' ecological preferences to determine the geographic distribution on Lanyu, (3) estimated Lanyu's population size, and (4) estimated the habitat change on Lanyu over the last half century.

\section{METHODS}

\section{Conservation status assessment}

To assess the current conservation status of the Japanese ParadiseFlycatcher, we gathered information from all recent publications and reports about the species' status in Japan, Korea, Taiwan, and the Philippines. Publications were found by (1) searching Google, Google Scholar, and Web of Science using the appropriate search terms (e.g., English and Latin species name, country names, etc.); (2) checking standard references (e.g., Brazil 1991, Brazil 2009, Coates et al. 2006, Severinghaus et al. 2010, 2017) and websites (e.g., BirdLife International 2015, HBW Alive 2016) for information and further references; (3) emailing any researcher whose email was given in these references and asking for further information and publications (any researcher who responded is mentioned in the Acknowledgements).

\section{Study site}

Lanyu $\left(21^{\circ} 58^{\prime}-22^{\circ} 06^{\prime} \mathrm{N}, 121^{\circ} 29^{\prime}-121^{\circ} 35^{\prime} \mathrm{E}\right)$, Taitung County, Taiwan, is located $64 \mathrm{~km}$ east off the southern tip of Taiwan. It is a $46.3 \mathrm{~km}^{2}$ mountainous volcanic island of mainly wooded habitats, generally shallow soil, and mostly steep topography. The tallest mountain is Mt. Hongtoushan at $552 \mathrm{~m}$ a. s. 1., and nearly 10 peaks are $>400 \mathrm{~m}$ (Fig. A1.1). The island is bounded by narrow strips of coastal flatlands (Fig. A1.4), and seven villages are located within these strips. The mean annual temperature is $22.7^{\circ}$ $\mathrm{C}$, and the mean annual rainfall is approximately $3000 \mathrm{~mm}$ with an average of about 220 rainy days (Taiwan Central Weather Bureau). Because of year-round heavy winds and frequent typhoons (usually several per year), the slopes are largely covered 
by dense shrubs and stunted trees while the occurrence of taller forests is confined to wind-sheltered plains and valleys (Chao et al. 2010). Although the most protected forests can reach a height of 20 meters, the forest canopy on slopes is usually around eight meters and, depending on wind exposure, even lower. Much of the taller forests of the coastal flatlands have been transformed into agricultural fields or frequently burned grasslands, while other accessible forests are structurally altered for the purpose of fruit production or construction wood (T. S., personal observation).

\section{Territory size estimation}

To estimate the territory size of male Japanese ParadiseFlycatchers, we selected five study plots that represented the various forest types found on the island and that were sufficiently accessible for frequent and intensive observations (some steep slopes are virtually inaccessible). From early March to late September 2009 and 2010, we censused each plot for the flycatcher's presence using conspecific playback at control points if we had not made spontaneous observations within the first few minutes after reaching the plot. The majority of these territories were occupied from late March, and no individuals left the island before September. Our observations also indicated that territorial borders became less distinct and that vocal activity or response to playback decreased as the breeding season progressed. We therefore chose April and May in 2010 as the period of highest territorial and vocal activity during which to carry out our islandwide census.

In 2009, we also captured flycatchers using mist nets at the same five study plots and color-banded each individual. We could furthermore distinguish uncaptured males in these study plots by differences in body characteristics, such as the length of tail feathers and aspects of plumage coloration on the throat, breast belly, mantle, greater coverts, and tail feathers. We then mapped out individual territories within each study plot between late March and late May. Once a week, each study plot was searched in the morning; points of encounters were recorded on a map based on high-resolution satellite images, and the bird was followed until we lost sight of it. These points were then used to plot the trajectory of the bird. The outermost points were later connected as a minimum convex polygon using Hawth's Tools for ArcGIS. The mean and standard deviation of 32 mapped territories was $1.16 \pm 0.43$ hectares (some mentioned in Severinghaus and Bai 2009, unpublished data cited in Appendix 1).

\section{Environmental data layers}

We assembled 22 environmental layers with a resolution of 100 $\mathrm{m}$ (or $0.1 \mathrm{x} 0.1 \mathrm{~km}$ or 1 hectare grid cell) for Lanyu (Table A1.1). The two normalized differenced vegetation index (NDVI) layers were generated from a satellite image taken by FORMOSAT-2 in April 2007 (Center for Space and Remote Sensing Research; http://www.csrsr.ncu.edu.tw/) with an $8 \mathrm{~m}$ multispectral resolution. We calculated the NDVI for each $8 \times 8 \mathrm{~m}$ pixel and summarized the mean and standard variation of the NDVI values in each 1 hectare grid cell (Fig. A1.2).

A digital terrain model (DTM) with $40 \mathrm{~m}$ resolution generated by the Aerial Survey Office (http://www.afasi.gov.tw/) was used to calculate four topographical data layers, namely elevation, aspect, slope, and solar irradiation for each 1 hectare grid cell.
These four data layers were then used to generate the data layers 3-13 (Table A1.1).

Based on the manual interpretation of aerial photographs taken in 1948 by the U.S. Airforce and in 2006 taken by the Aerial Survey Office, we created two layers of land cover types using ArcGIS that included the following categories: (1) roads; (2) bare coastal land (beach, rock); (3) other built-over land (buildings, parking spaces, etc.); (4) farmland or grassland; (5) hilltop shrub; (6) stunted forest; (7) tall forest (either mixed mature forests or forests dominated by mature Pometia pinnata; Fig. A1.3), (8); other types, e.g., landslides, inland water, etc. Stunted forest contained both low secondary forests and primary shrubby woodland on wind exposed slopes because these two types could not be differentiated in the aerial photographs. These two data layers were used to generate the data layers 14-22 (Table A1.1). To characterize the land cover types of each grid cell, we calculated the percentage value of each type for each cell (data layers 14-21 in Table A1.1), and finally used the same data to generate a categorical data layer, which corresponded to the dominant land cover type of each grid cell (data layer 22 in Table A1.1). Only this data layer 22 of the dominant land cover types was generated for both 1948 and 2006 in order to assess habitat change.

\section{Modeling species distribution}

Because we had established that male territories were about one hectare, we used ArcGIS to establish 1 hectare (100 m x $100 \mathrm{~m}$ ) grid cells as sampling units across the entire island. Any grid cells that were not entirely covered by land surface were a priori excluded. We then used Hawth's Tools for ArcGIS to randomly select 224 grid cells among the remaining grid cells, which represent about $5 \%$ of Lanyu's total land surface. Because of our limited resources and the island's rugged terrain that renders many parts inaccessible, we a priori chose this $5 \%$ threshold, which was the maximum number of grid cells that we could reasonably survey during the period of the flycatcher's highest territorial activity, i.e., April and May.

Each grid cell was visited once between sunrise and noon during April and May 2010. Once the center of the grid cell had been reached, we waited for spontaneous calls or songs for up to three minutes; if none were detected, we used playback consisting of recordings of calls and songs of the local population and played them up to three times at three minute intervals to elicit a response. The species was defined to be present if it was detected visually or acoustically during this time, and was defined to be absent from the respective grid cell if it could not be heard or seen during this one visit.

This protocol for detecting presence was based on our preliminary field work. During our regular controls of the five study plots but also when checking additional transect lines, we used playback at fixed control points to check for the presence or absence of the territorial male if it could not be detected by visual or acoustic detection. We found that there was no significant effect of time of day on the playback response, and that we never failed to detect the territorial male even if the playback was conducted only in the grid cell's center. Therefore, we are confident that our method of detection was reliable.

However, we are aware that absence is much harder to establish than presence, and that some of the absence records in Fig. 2 may 
be false absences. For this reason, we chose a modeling software that only needs presence records, namely Maxent. Therefore, our absence records were not used further in the modeling analyses described below.

Fig. 2. Location of presence (red, $n=120$ ) and absence (blue, $n$ $=104$ ) grid cells for the Japanese Paradise-Flycatcher (Terpsiphone atrocaudata) across Lanyu, Taiwan, in 2010.

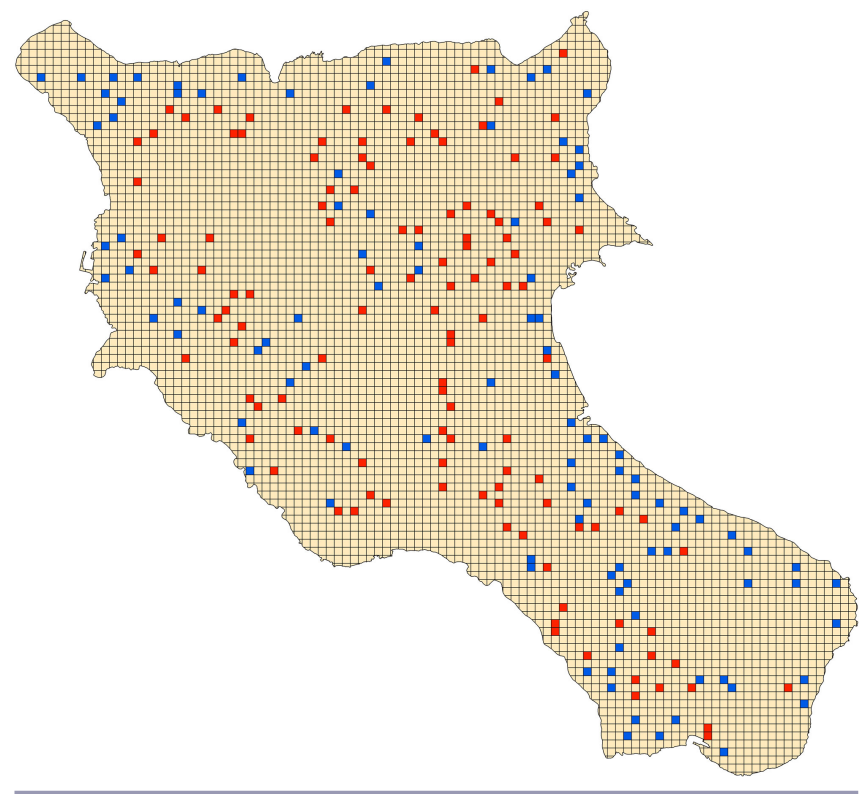

We avoided multicollinearity and overfitting in our Maxent distribution models by reducing our original set of 21 continuous variables, i.e. environmental data layers, to eight variables (Table A1.1). We assessed collinearity by constructing a correlation matrix for the 21 variables based on Spearman's correlation coefficient $\left(r_{s}\right)$, and we removed all but one variable if $r_{s}$ was $>$ 0.80 between two or more variables. In each case, we kept only the variable with the highest percent contributions across the 48 global Maxent models which we initially ran.

With this reduced set of eight continuous variables and one categorical variable (dominant land cover type), we generated suitability distributions for the Japanese Paradise-Flycatcher across Lanyu using the maximum entropy algorithm implemented in the software Maxent (Phillips et al. 2006, Phillips and Dudík 2008, Elith et al. 2011). We used Maxent with the logistic output of probabilities. Maxent finds the probability distribution of maximum entropy subject to constraints imposed by the information available from the observed distribution of the species and environmental conditions across the study area. Thereby, Maxent transforms environmental variables into feature vectors and then uses entropy as the means to generalize specific observations of the species' presence; therefore, it does not require absence points within its theoretical framework.

Recommended default values for the Maxent modeling procedure were used for the convergence threshold (10-5), maximum number of iterations (500), data being randomly divided into $70 \%$ training and 30\% testing data, and cross-validation using jackknife resampling. The selection of "features" (environmental variables or functions thereof) was also carried out automatically, following default rules dependent on the number of presence records.

In order to obtain the most suitable model for our data, we generated 48 models by varying the following modeling features:

1. The number of background points was varied at four settings: 500, 1000, 2500, and 5000.

2. The modeling features were varied with three categories: linear, quadratic, and linear + quadratic (cf. BoteroDelgadillo et al. 2015a,b).

3. The regularization multiplier (also called regularization constant or beta-multiplier) was varied at four equidistant intervals: 0.25, 0.50, 0.75, and 1.00 (cf. Botero-Delgadillo et al. $2015 a, b)$.

In this way, we generated $4 \times 4 \times 3=48$ models for comparison. First, we generated 48 models using all 22 environmental variables, but only to score the heuristic estimates of each variable's relative model contribution and average each variable's mean contribution over the entire 48 models. This average percent contribution was then used to eliminate highly correlating variables. We then generated another 48 models using the same combination of modeling features but with only the remaining nine variables (eight continuous variables plus one categorical variable).

We then evaluated the support for each of these 48 competing models using the likelihood-based methods based on the information theoretic approach proposed in Burnham and Anderson (2002). We ranked models based on the Akaike's Information Criterion adjusted for small sample size (AICc), and we accepted only those models with an AICc difference ( $\triangle \mathrm{AICc}$ ) $<2$ as having "substantial" support (sensu page 70 in Burnham and Anderson 2002; see also Majić et al. 2011, Grabowska-Zhang et al. 2012, Hong et al. 2016). These are also the models with the largest Akaike weights (Wi) and the smallest evidence ratios (Burnham and Anderson 2002).

To choose a final model, the best model with the lowest $\triangle \mathrm{AICc}=$ zero can be used (e.g., Botero-Delgadillo et al. 2015a, $b$ ). However, we chose to adopt the strategy of Burnham and Anderson (2002) whereby all models with substantial support should be considered as having value. Therefore, we generated an ensemble model (sensu Araújo and New 2007) as our final model by combining all the models with substantial support $(\triangle \mathrm{AICc}<2)$. Although there are also several ways of combining models (M. Araújo, 2012, personal communication), we simply calculated the mean of all the models that were included into the final ensemble model.

Maxent also generates response curves, which show how each environmental variable affects the prediction. These response curves reflect the dependence of predicted suitability both on the selected variable and on dependencies induced by correlations between the selected variable and other variables (Phillips 2017). We examined these response curves to check model fit and how the environmental variable affects the prediction.

As recommended by Botero-Delgadillo et al. (2015a,b), model significance was also evaluated with threshold-dependent binomial probability tests applied in each replicate, and model performance was evaluated with the mean values and standard 
Fig. 3. Frequency distributions depicting the variation in (A) mean elevation, (B) percentage of tall forest, and (C) mean normalized differenced vegetation index (NDVI) associated with the 120 presence grid cells for the Japanese Paradise-Flycatcher (Terpsiphone atrocaudata). Note that the bimodal distribution in Fig. 3B results from the species' preference for stunted forest (left peak; see also Fig. A1.2) and tall forest (right peak).
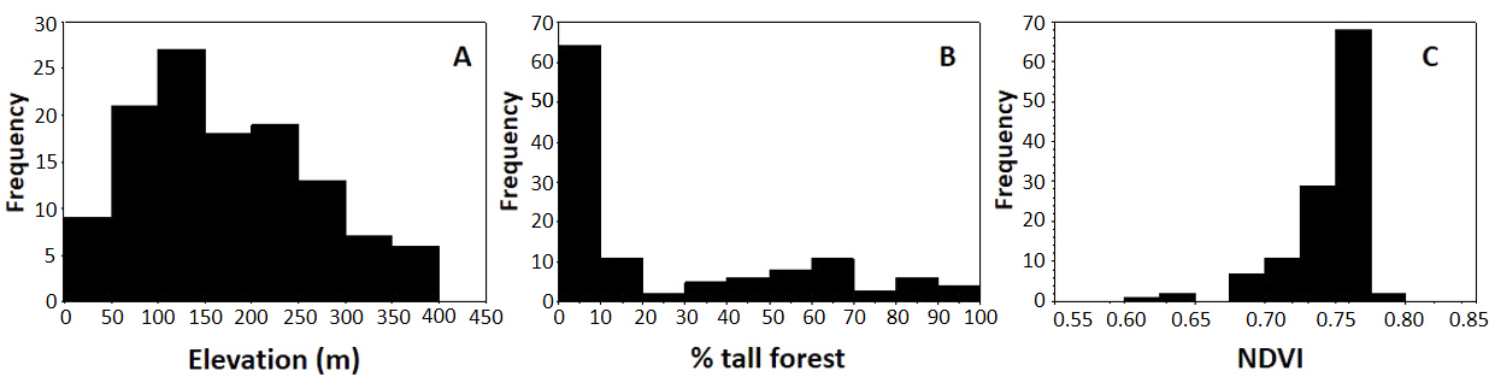

deviations of the regularized training gain values, the thresholdbased omission error rates on training and test data, as well as the AICc.

The best models based on AICc were also evaluated with the 5fold cross-validation technique (Peterson et al. 2011). Four runs of the cross-validation procedure were obtained through data reshuffling, which produced a total of 20 model replicates that were used to assess uncertainty around the estimates of model performance and significance (Botero-Delgadillo et al. 2015a,b).

Finally, we used the minimum training presence threshold (Phillips et al. 2006) to obtain a binary spatial projection of environmental suitability, i.e. to transform the logistic model output from Maxent into a presence-absence grid map, because it minimizes the inclusion of commission errors in model testing (Botero-Delgadillo et al. 2015a,b). All these analyses were carried out with Maxent version 3.4.1 (Phillips 2017), ArcGIS version 10.1, and ENMTools version 1.4.4 (Warren et al. 2010).

\section{Population size estimate}

To estimate population size, we divided the size of the entire area deemed suitable in the binary distribution map generated using the minimum training presence threshold by the mean estimated size of a male's territory, namely $1.16 \pm 0.43$ hectares. It should be noted that this estimation assumes that every territory is occupied.

\section{Habitat change assessment}

Our results below demonstrate that the Japanese ParadiseFlycatcher occurred almost exclusively in hilltop shrub, stunted forest, and tall forest. For our historical comparison of habitat change, we therefore lumped these three land cover types into one type called "forest." We then compared the forest area of 1948 to the forest area of 2006 using data layer 22 (Table A1.1) to assess the amount of change in the area of habitat that is potentially suitable for the Japanese Paradise-Flycatcher.

\section{RESULTS}

\section{Conservation status assessment}

A brief assessment of the current conservation status of the Japanese Paradise-Flycatcher in Japan, Korea, Taiwan, and the Philippines is given in Appendix 1. From the available but relatively sparse information, it appears that the Japanese population is now stable after a decline between the 1970s and 1990 s, that the Korean population is probably stable or slightly increasing (although some experts contended that the species has been decreasing), the Taiwanese population is stable, while the status of the Philippine population is unknown although it was certainly present in 2006 and 2007.

\section{Modeling species distribution}

The field work in 2010 established 120 presence and 104 absence grid cells (Fig. 2). Almost all presence grid cells were at some distance from the coastline, i.e., almost no singing males were found in the coastal lowlands. Away from coastal areas, the presence grid cells were distributed relatively evenly across the entire island, from north to south and east to west. The means, variations, and ranges of the environmental values within the presence and absence grid cells are given in Table A1.2.

The presence grid cells covered an elevational range from 16-399 $\mathrm{m}$ with a mean of $172 \mathrm{~m}$ (Table A1.2, Fig. 3A). The area of tall forests within the presence grid cells ranged from $0-100 \%$, with a mean percentage of $26 \%$ (Fig. 3B). Furthermore, 115 out of the 120 presence grid cells (or $96 \%$ ) ranged from $0.68-0.77$ for mean NDVI, with a mean of 0.74 (Fig. 3C). The dominant land cover types for the presence grid cells were farm/grassland (5 grid cells), hilltop shrub (6 grid cells), stunted forest ( 77 grid cells), and tall forest (32 grid cells). Therefore, grid cells containing either mostly stunted forest (Fig. A1.5) or mostly tall forest (Fig. 3B) represented $91 \%$ of all the presence grid cells. Furthermore, grid cells containing mostly one of the three "forest" types (namely, hilltop scrub, stunted forest, or tall forest) represented $96 \%$ of all the presence grid cells. To summarize, the Japanese ParadiseFlycatcher was detected mostly at midelevations of 50-300 m, preferred the areas of Lanyu with the highest NDVI values, and was found almost exclusively in forest, and predominantly in stunted or tall forest.

We ran Maxent with the nine selected environmental variables and used them to construct 48 models. Of these 48 models, five models had a $\triangle \mathrm{AICc}<2$ (Table A1.3).

For these five "best" models, the mean regularized training gains were $0.49 \pm 0.04(\mathrm{n}=5 * 20$ replicates $=100$ replicates, same below), the mean values of the threshold-based training omission 
Table 1. Heuristic estimates of the relative contribution and relative performance of nine environmental variables to modeling the distribution of the Japanese Paradise-Flycatcher (Terpsiphone atrocaudata) on Lanyu Island, Taiwan. The variables are ordered by their mean percent contribution. NDVI = normalized differenced vegetation index.

\begin{tabular}{lccc}
\hline \hline Environmental variable & Mean percent contribution $^{\dagger}$ & Training gain without $^{\ddagger}$ & Training gain with only $^{\S}$ \\
\hline altitude mean & $25.20 \pm 5.76$ & $0.401 \pm 0.020$ & $0.249 \pm 0.013$ \\
\% tall forest & $16.37 \pm 2.99$ & $0.475 \pm 0.024$ & $0.190 \pm 0.012$ \\
NDVI mean & $12.85 \pm 4.80$ & $0.479 \pm 0.027$ & $0.196 \pm 0.008$ \\
\% bare coastal land & $9.74 \pm 3.56$ & $0.507 \pm 0.024$ & $0.106 \pm 0.005$ \\
\% hilltop shrub & $9.72 \pm 1.47$ & $0.487 \pm 0.022$ & $0.026 \pm 0.004$ \\
\% farm/grassland & $8.30 \pm 1.32$ & $0.475 \pm 0.022$ & $0.059 \pm 0.006$ \\
dominant land cover type & $7.35 \pm 4.03$ & $0.507 \pm 0.024$ & $0.194 \pm 0.013$ \\
altitude std. dev. & $5.91 \pm 1.00$ & $0.490 \pm 0.023$ & $0.133 \pm 0.010$ \\
\% aspect south & $4.55 \pm 3.93$ & $0.489 \pm 0.022$ & $0.022 \pm 0.002$ \\
\hline
\end{tabular}

†Values represent each variable's mean percent contribution (\%) \pm 1 standard deviation.

"Values represent the model's training gain achieved with all but the regarded variable \pm 1 standard deviation.

${ }^{\S}$ Values represent the model's training gain achieved with only the regarded variable and excluding the remaining eight variables \pm 1 standard deviation.

Fig. 4. The ensemble distribution model of the Japanese Paradise-Flycatcher (Terpsiphone atrocaudata) across Lanyu, Taiwan, shown as a probability surface (see text for details). Probability values are depicted in two colors from lowest (blue) to highest (red) in 10 equal intervals.

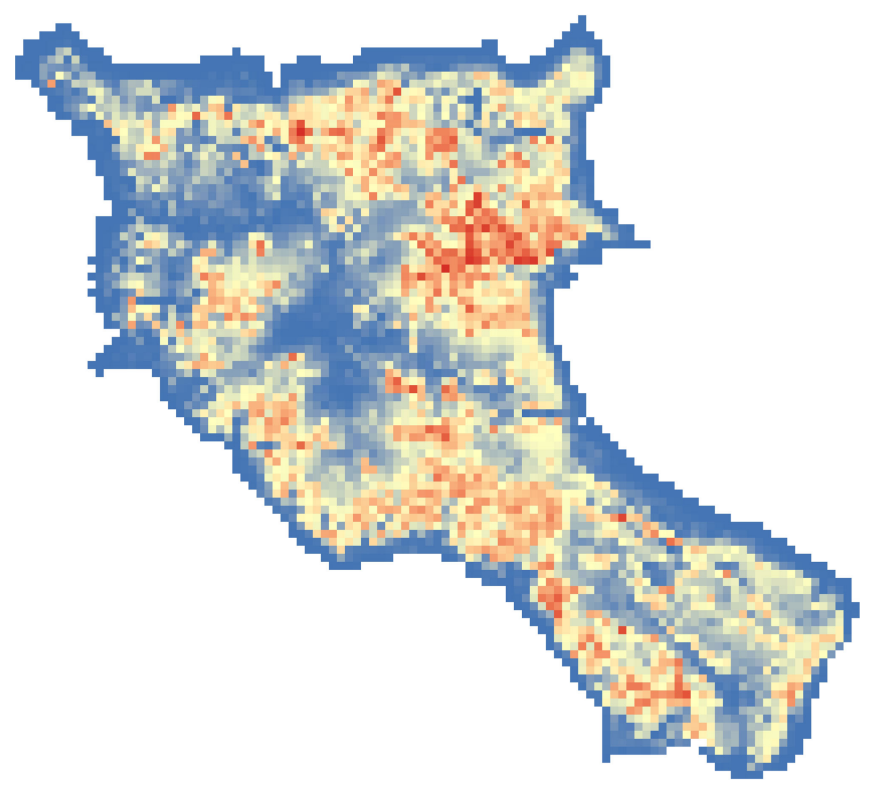

error rates were $0.07 \pm 0.02(\mathrm{n}=100)$, and the threshold-based test omission error rates were $0.17 \pm 0.05(\mathrm{n}=100)$, thereby confirming that these models performed reasonably well. All cross-validation replicates of these models were statistically significant according to the threshold-dependent binomial probability test (all $\mathrm{P}<0.05)$.

Among these 48 models, the three variables that were almost consistently chosen as the variables with the highest heuristic estimates of their relative model contribution were mean elevation, percentage of tall forest, and mean NDVI, having a combined contribution of $54.4 \%$ (Table 1). Although these three variables did not yield the highest training gain achieved with all
Fig. 5. The binary distribution model of Japanese ParadiseFlycatcher (Terpsiphone atrocaudata) across Lanyu, Taiwan, using the minimum training presence threshold to turn the probability surface depicted in Fig. 4 into a binary map with modeled presence (black, $n=1203$ ) and absence (grey, $n=$ 3429) grid cells.

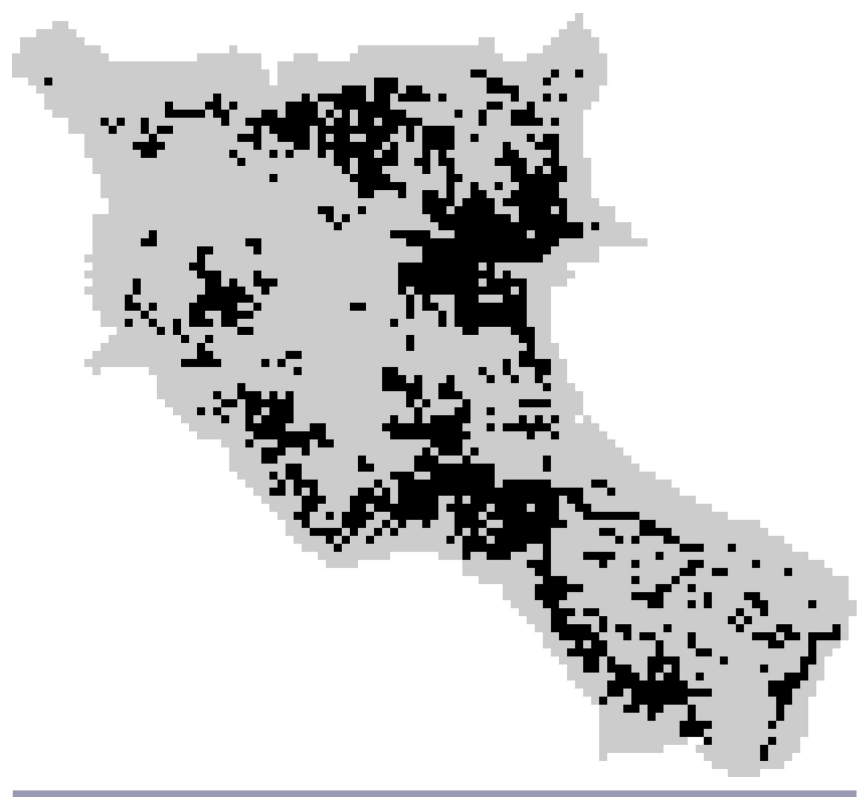

but the regarded variable, these three variables achieved the highest training gain achieved with only the regarded variable, with one exception, namely dominant land cover type (Table 1).

We combined these five models into an ensemble model (Fig. 4). Using the minimum training presence threshold, we then converted this ensemble model into a binary map of the estimated ecological niche of the Japanese Paradise-Flycatcher on Lanyu Island (Fig. 5). This binary map covers 1203 out of a total of 4632 grid cells, or $26.0 \%$ of the island's surface (equaling $12.03 \mathrm{~km}^{2}$ ).

After modeling environmental suitability as a function of these nine variables, the individual response curves generated by Maxent for the three most important environmental variables 
Fig. 6. The probability of presence of the Japanese Paradise-Flycatcher (Terpsiphone atrocaudata) in relation to spatial variation in (A) mean elevation (in m); (B) percentage of tall forest; and (C) mean normalized differenced vegetation index (NDVI; unitless) in Lanyu Island, Taiwan. Each individual response curve was generated by Maxent, with the curve representing the Maxent model created by using only the respective variable. Here, we used the curves generated for the best model $(\triangle \mathrm{AICc}=0)$. The vertical axis represents the probability of presence from the logistic output of Maxent model. The red line shows the average of the 100 replicate runs, while the blue lines shows \pm 1 standard deviation.
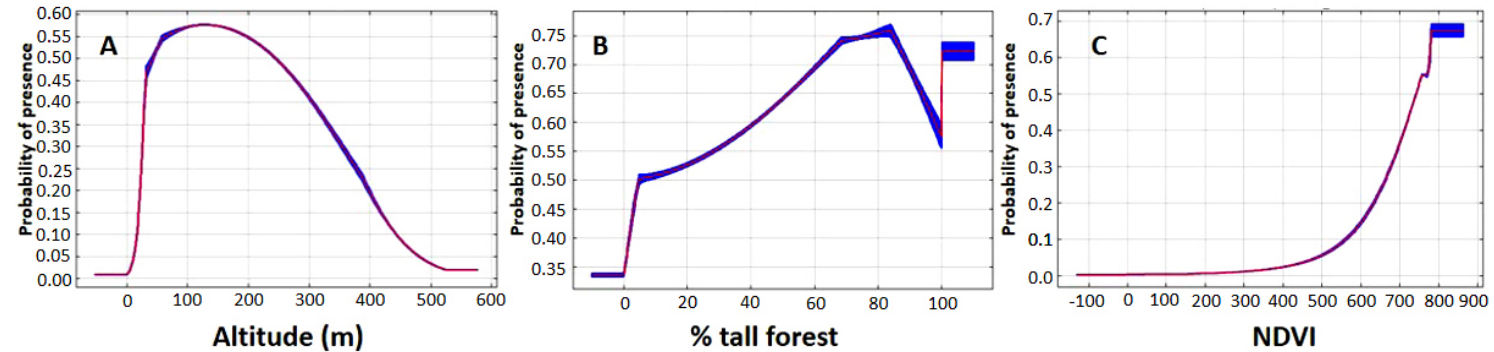

indicated that environmental suitability for the Japanese ParadiseFlycatcher was highest at midelevations of about 30-350 m (Fig. $6 \mathrm{~A})$ and increased with the percentage of tall forest within the grid cell (Fig. 6B) and with NDVI (Fig. 6C). These results generated by Maxent therefore correspond reasonably well with the results from the presence grid cells (Fig. 3).

\section{Population size estimate}

Because the average size of a male's territory was $1.16 \pm 0.43$ hectares, we extrapolated that the area deemed suitable in the binary distribution map (namely $12.03 \mathrm{~km}^{2}$ ) could hold 1037.1 territories. If we use the lower and upper estimates given by the standard deviation ( 0.73 and 1.59 , respectively), we can calculate an upper and lower limit of the number of male territories of 1647.9 territories and 756.6 territories, respectively.

\section{Habitat change assessment}

Our historical comparison of the availability of "forest" revealed that very small areas of forest were lost between 1948 and 2006 (specifically, $0.66 \mathrm{~km}^{2}$ or $1.43 \%$ of the island's area). Almost all of these areas are located near the coast (Fig. A1.6). During the same time period, relatively large areas of forest were gained (specifically, $8.23 \mathrm{~km}^{2}$ or $17.77 \%$ of the island's area). These areas are distributed across the entire island, but especially in the areas just south of the island's center (Fig. A1.7). The net gain of forest areas was therefore $7.57 \mathrm{~km}^{2}$ (or $16.35 \%$ of the island's area).

Some of these gained forest areas are located within our binary presence model (Fig. A1.8), and this gained area covers $3.76 \mathrm{~km}^{2}$ (or $8.13 \%$ of the island's area). Assuming that the Japanese Paradise-Flycatcher's habitat preference for the three "forest" categories did not change between 1948 and 2006, and that other important variables, e.g., territory size, also did not change, this area of potentially suitable habitat gained from 1948 to 2006 could support an additional 324.3 male territories, or $31.27 \%$ of the entire 1037.1 territories.

\section{DISCUSSION}

Our field work indicates that males of the periophthalmica subspecies of the Japanese Paradise-Flycatcher found on Lanyu Island prefer to establish territories in midelevational forest habitats that include both stunted and tall forests and that have relatively high NDVI values. Using the 120 presence locations from our field work, we produced an ensemble model of the flycatcher's ecological niche that estimates that such suitable habitat extends over about $12.0 \mathrm{~km}^{2}$ or about $26 \%$ of Lanyu's area. Because our field work also established that the average size of a male's territory is $1.16 \pm 0.43$ hectares, we could extrapolate that approximately 1037 territories may exist on Lanyu Island, with upper and lower limits of approximately 1648 territories and 757 territories, respectively.

However, we note that any such population size estimate is associated with various uncertainties, such as that not all potential territories may be occupied, that there may be annual variations in population size, and that the use of different thresholds (Nenzén and Araújo 2011) than the one we used (minimum training presence threshold) would have resulted in different estimates of the area of suitable habitat. Nevertheless, even with these uncertainties, our estimate is a substantial increase over previous estimates of $<100$ breeding pairs (Brazil 2009) and < 500 individuals (Fang 2005).

Our results can also be used to design conservation measures for the Lanyu population because our results suggest that the Japanese Paradise-Flycatcher prefers relatively wet midelevational forest habitats. Currently, the Lanyu population is probably not threatened in its preferred habitat because limited land use conversion has been occurring in Lanyu, with an overall net gain of $7.57 \mathrm{~km}^{2}$ of forest habitats between 1948 and 2006, which, all other things being equal, should have resulted in a population increase of around $30 \%$. Despite the fact that the local population rejected a plan to turn parts of the island into a national park in the 1980s and 1990s (Huang 1997), there are currently no socioeconomic factors that would drive forest destruction or conversion. Therefore, continuous monitoring and maintenance of this suitable forest habitat should ensure the long-time survival of this species, assuming no stochastic catastrophic events, such as typhoons, or long-term changes, such as climate change.

Consequently, the question arises whether the Japanese Paradise-Flycatcher should remain in the "near-threatened" 
category. The main reason given by BirdLife International (2015) is that declines were noted in parts of Japan's breeding range that were presumably caused mostly by habitat loss and degradation within the wintering grounds. However, as outlined in Appendix 1 , this assessment is based mostly on relatively old studies and only from parts of Japan. Since then, its status in Japan appears unchanged since the 1990s, including the Ryukyu population $(\mathrm{H}$. Higuchi, 2015, personal communication). Our study suggests that the Lanyu population is also relatively safe, and despite some yearly fluctuations (L. L. S., unpublished data), it may even have increased over the last half century because of habitat expansion, although there are no historical data on population numbers to confirm or reject this supposition.

Finally, the Korean population may have been increasing, which could be due to a northward expansion due to climate change (e.g., Kwon et al. 2014, Wu and Shi 2016) and successful reforestation, although other experts considered this to be an artificial effect derived from increased sampling effort or even contended that the species has been decreasing (Appendix 1). If the Philippine population is also found to be stable (pending further study), a case could be made for down-listing the species to "least concern." However, there remains an urgent need to find out more about this species' migration routes and wintering grounds because habitat loss and degradation in the wintering grounds were suspected to have caused the original decline of the Japanese populations (BirdLife International 2015). With rainforest habitats continuing to decline rapidly across Southeast Asia (Wilcove et al. 2013, Walther et al. 2016), it is likely that the Japanese Paradise-Flycatcher is being impacted by these environmental changes. Given rapid environmental changes, the continuous reassessment of the conservation status of Taiwan's birds (Walther et al. 2011, Wu et al. 2014, Lin et al. 2016) and East Asia's birds (Collar et al. 2001, Kirby et al. 2008) must remain a research priority.

Consequently, we have four main recommendations concerning the T. a. periophthalmica subspecies:

1. Because there is no reliable population estimate for the Philippine population (Appendix 1), a study of the size of the Philippine breeding population should be a conservation priority.

2. Further monitoring and protection of Taiwan's breeding population should be a conservation priority for Taiwanese researchers and authorities.

3. A study of the species' migration and wintering grounds is overdue, including changes and threats to suitable habitats in these grounds.

4. A study to determine if this subspecies actually deserves full species status (e.g., McGregor 1907, Alcasid 1965) should be a priority for taxonomists.

Indeed, further taxonomic and genetic studies are warranted for all the subspecies (or even all of its independent conservation units) of the Japanese Paradise-Flycatcher because some or all of its subspecies may be sufficiently distinct to merit full species status. If, for example, T. a. periophthalmica was to be elevated to species status, its conservation status might be "nearthreatened" or even "vulnerable" (IUCN 2012) because of its existence in only five known locations (Lanyu and the four Batanes islands), small geographic range $\left(\sim 12 \mathrm{~km}^{2}\right.$ on Lanyu and unknown in Batanes), and its relatively small population size ( 1000 singing males on Lanyu and unknown in Batanes). Under the IUCN criteria, species with either small populations $(<10,000$ individuals) or small areas of occupancy $\left(<2000 \mathrm{~km}^{2}\right)$ may be classified as vulnerable, regardless of the trajectory of their populations. T. a. periophthalmica would fulfil both of these criteria.

Even if T. a. periophthalmica was not elevated to species status, these two island populations could justifiably be considered independent conservation units, especially given that they are the only populations within either Taiwan or the Philippines. Island populations as independent conservation units have been proposed for other island bird populations (e.g., Dudaniec et al. 2011, Garcia-del-Rey et al. 2013, Ando et al. 2014, Forcina et al. 2014, Pruett et al. 2017). Conservation units have also been called evolutionarily significant units or management units (cf. Moritz 1994, Rayner et al. 2010). However, these studies have routinely included genetic analyses, which were not part of our study, again emphasizing the need for more genetic and taxonomic studies of this species.

The Lanyu and Batanes islands are regularly subjected to devastating super typhoons (e.g., Fritz 2016), with no information about the impact of these typhoons on local bird populations (although see Hong et al. 2016 for an example from Taiwan's mainland). This lack of information about the recent fate of these island populations further underlines the need for more continuous field work, especially in Batanes, but also in Lanyu. We therefore recommend that the governments of Taiwan and the Philippines should support future research on bird populations on islands that could be designated as independent conservation units. We further recommend that more continuous monitoring of such populations is financed, because the only continuous field work on the Lanyu population is the one reported in this study which lasted for only two breeding seasons. Although the recently established Taiwan Breeding Bird Survey (Ko et al. 2015 ) is a step in the right direction, more long-term monitoring targeted at specific species and populations (e.g., Lin et al. 2007) is required.

Responses to this article can be read online at: http://www.ace-eco.org/issues/responses.php/1167

\footnotetext{
Acknowledgments:

We are grateful to Gui-Qing Wang for providing valuable personal field observations from Lanyu, and Chin-Kuo Lee for interpreting aerial photographs of Lanyu. We thank Mark Brazil, Amy Chernasky, Chang-Yong Choi, Mike Crosby, Juan Carlos Tecson Gonzalez, Hiroyoshi Higuchi, Han-kyu Kim, Jin-Won Lee, RueyShing Lin, and Carl Oliveros for providing references and additional information, Tsai-Yu Wu for help with modelling, Tsai-Yu Wu and $Y u$-Wen Emily Dai for translations, and several reviewers for comments. BAW was financially supported by Taipei Medical University. TS was financially supported by a grant from German Academic Exchange Service (DAAD). Covering the costs for
} 
overall logistics, material, and additional support by field assistants was only possible because of substantial funding from Forestry Bureau of Council of Agriculture of Executive Yuan and Academia Sinica.

\section{LITERATURE CITED}

Alcasid, G. L. 1965. Terpsiphone atrocaudata on Mindoro, Philippines. Auk 82:644. http://dx.doi.org/10.2307/4083230

Ando, H., H. Ogawa, S. Kaneko, H. Takano, S.-I. Seki, H. Suzuki, K. Horikoshi, and Y. Isagi. 2014. Genetic structure of the critically endangered Red-headed Wood Pigeon Columba janthina nitens and its implications for the management of threatened island populations. Ibis 156:153-164. http://dx.doi.org/10.1111/ibi.12120

Araújo, M. B., and M. New. 2007. Ensemble forecasting of species distributions. Trends in Ecology and Evolution 22:42-47. http://dx. doi.org/10.1016/j.tree.2006.09.010

BirdLife International. 2015. Species factsheet: Japanese Paradise-Flycatcher Terpsiphone atrocaudata. BirdLife International, Cambridge, UK. [online] URL: http://www.birdlife.org/ datazone/species/factsheet/22707151

Botero-Delgadillo, E., N. Bayly, S. Escudero-Páez, and M. I. Moreno. 2015a. Understanding the distribution of a threatened bird at multiple levels: a hierarchical analysis of the ecological niche of the Santa Marta Bush-Tyrant (Myiotheretes pernix). Condor 117:629-643. http://dx.doi.org/10.1650/CONDOR-15-26.1

Botero-Delgadillo, E., N. Bayly, C. Gómez, P. C. Pulgarín-R., and C. A. Páez. 2015b. An assessment of the distribution, population size and conservation status of the Santa Marta foliage-gleaner Automolus rufipectus: a Sierra Nevada de Santa Marta endemic. Bird Conservation International 25:451-465. http://dx.doi. org/10.1017/S0959270914000513

Brazil, M. A. 1991. The birds of Japan. Christopher Helm, London, UK.

Brazil, M. 2009. Birds of East Asia: China, Taiwan, Korea, Japan, and Russia. Princeton University Press, Princeton, New Jersey, USA.

Burnham, K. P., and D. R. Anderson. 2002. Model selection and inference: a practical information-theoretic approach. Second edition. Springer Verlag, New York, New York, USA. http://dx. doi.org/10.1007/978-1-4757-2917-7

Chao, W.-C., G.-Z. M. Song, K.-J. Chao, C.-C. Liao, S.-W. Fan, S.-H. Wu, T.-H. Hsieh, I.-F. Sun, Y.-L. Kuo, and C.-F. Hsieh. 2010. Lowland rainforests in southern Taiwan and Lanyu, at the northern border of Paleotropics and under the influence of monsoon wind. Plant Ecology 210:1-17. http://dx.doi. org/10.1007/s11258-009-9694-0

Coates, B. J., G. C. L. Dutson, C. E. Filardi, P. Clement, P. A. Gregory, and C. W. Moeliker. 2006. Family Monarchidae (monarch-flycatchers). Pages 244-329 in J. del Hoyo, A. Elliott, and D. Christie, editors. Handbook of the birds of the world. Vol. 11. Old World flycatchers to Old World warblers. Lynx Edicions, Barcelona, Spain.
Collar, N. J., A. V. Andreev, S. Chan, M. J. Crosby, S. Subramanya, and J. A. Tobias, editors. 2001. Threatened birds of Asia: the BirdLife International red data book. BirdLife International, Cambridge, UK.

Ding, T.-S., C.-S. Juan, R.-S. Lin, C.-Y. Pan, Y.-J. Tsai, J. Wu, and Y.-H. Yang. 2014. The 2014 CWBF checklist of the birds of Taiwan. Bird Record Committee, Chinese Wild Bird Federation, Taipei, Taiwan. [online] URL: http://birdingattaiwan.com/

The_2014_CWBF_Checklist.pdf

Duckworth, J. W., and N. Moores. 2008. A re-evaluation of the pre-1948 Korean breeding avifauna: correcting a 'founder effect' in perceptions. Forktail 24:25-47. [online] URL: http:// birdingasia.org/wp-content/uploads/2012/10/Duckworth-Korea. pdf

Dudaniec, R. Y., B. E. Schlotfeldt, T. Bertozzi, S. C. Donnellan, and S. Kleindorfer. 2011. Genetic and morphological divergence in island and mainland birds: informing conservation priorities. Biological Conservation 144:2902-2912. http://dx.doi.org/10.1016/ j.biocon.2011.08.007

Elith, J., S. J. Phillips, T. Hastie, M. Dudík, Y. E. Chee, and C. J. Yates. 2011. A statistical explanation of MaxEnt for ecologists. Diversity and Distributions 17:43-57. http://dx.doi.org/10.1111/ j.1472-4642.2010.00725.x

Fang, W.-H. 2005. A guide to threatened birds of Taiwan. Owl Publishing House, Taipei, Taiwan.

Forcina, G., P. Panayides, N. Kassinis, M. Guerrini, and F. Barbanera. 2014. Genetic characterization of game bird island populations: the conservation of the Black Francolin (Francolinus francolinus) of Cyprus. Journal for Nature Conservation 22:15-22. http://dx.doi.org/10.1016/j.jnc.2013.07.004

Fritz, A. 2016. Remember the island in the super typhoon eye? Not a single person died, reports say. Washington Post, 20 September. [online] URL: https://www.washingtonpost.com/ news/capital-weather-gang/wp/2016/09/20/remember-the-islandin-the-super-typhoon-eye-not-a-single-person-died-reports-say/? utm_term $=$.bab57a84ab9b

Garcia-del-Rey, E., G. Marthinsen, P. Calabuig, L. Estévez, L. E. Johannessen, A. Johnsen, T. Laskemoen, and J. T. Lifjeld. 2013. Reduced genetic diversity and sperm motility in the endangered Gran Canaria blue chaffinch Fringilla teydea polatzeki. Journal of Ornithology 154:761-768. http://dx.doi.org/10.1007/s10336-013-0940-9

Gonzalez, J. C. T., L. E. Afuang, and A. V. Lacaste. 2008. Identifying conservation priorities for terrestrial vertebrate fauna in the Batanes Islands, northern Philippines. Journal of Nature Studies 7:1-8.

Grabowska-Zhang, A. M., T. A. Wilkin, and B. C. Sheldon. 2012. Effects of neighbor familiarity on reproductive success in the Great Tit (Parus major). Behavioral Ecology 23:322-333. http:// dx.doi.org/10.1093/beheco/arr189

Handbook of the Birds of the World (HBW) Alive. 2016. Japanese Paradise-Flycatcher (Terpsiphone atrocaudata). Lynx Edicions, Barcelona, Spain. [online] URL: http://www.hbw.com/species/ japanese-paradise-flycatcher-terpsiphone-atrocaudata 
Hong, S.-Y., B. A. Walther, M.-C. Chiu, M.-H. Kuo, and Y.-H. Sun. 2016. Length of the recovery period after extreme flood is more important than flood magnitude in influencing reproductive output of Brown Dippers (Cinclus pallasii) in Taiwan. Condor 118:640-654. http://dx.doi.org/10.1650/CONDOR-16-1.1

Huang, Y.-W. 1997. An analysis of decision-making process of establishing Lanyu National Park. Journal of Geographical Science 23:13-31.

International Union for Conservation of Nature (IUCN). 2012. IUCN Red List categories and criteria: Version 3.1. Second edition. IUCN, Gland, Switzerland and Cambridge, UK. [online] URL: http://s3.amazonaws.com/iucnredlist-newcms/staging/public/ attachments/3097/redlist_cats_crit_en.pdf

Jeyarajasingam, A., and A. Pearson. 2012. A field guide to the birds of Peninsular Malaysia and Singapore. Oxford University Press, Oxford, UK.

Johnson, T. H., and A. J. Stattersfield. 1990. A global review of island endemic birds. Ibis 132:167-180. http://dx.doi.org/10.1111/ j.1474-919X.1990.tb01036.X

Kennedy, R. S., P. C. Gonzales, E. C. Dickinson, H. C. Miranda, and T. H. Fisher. 2000. A guide to the birds of the Philippines. Oxford University Press, Oxford, UK.

Kier, G., H. Kreft, T. M. Lee, W. Jetz, P. L. Ibisch, C. Nowicki, J. Mutke, and W. Barthlott. 2009. A global assessment of endemism and species richness across island and mainland regions. Proceedings of the National Academy of Sciences of the United States of America 106:9322-9327. http://dx.doi.org/10.1073/ pnas.0810306106

Kirby, J. S., A. J. Stattersfield, S. H. M. Butchart, M. I. Evans, R. F. A. Grimmett, V. R. Jones, J. O'Sullivan, G. M. Tucker, and I. Newton. 2008. Key conservation issues for migratory land- and waterbird species on the world's major flyways. Bird Conservation International 18 (Supplement 1):S49-S73. http://dx.doi. org/10.1017/S0959270908000439

Ko, C.-J., M.-W. Fan, Y.-X. Jiang, W.-J. Yu, Y.-Y. Lo, R.-S. Lin, K. Lin, and P.-F. Lee. 2015. 2013 Taiwan breeding bird survey. Annual Report. Endemic Species Research Center, Council of Agriculture, Endemic Species Research Institute, Nantou, Taiwan. [online] URL: https://www.researchgate.net/ publication/273026543_2013_Taiwan_Breeding_Bird_Survey_Annual_Report_taiwanfanzhiniaoleidadiaocha2013nianbao_Traditional_Chinese_version

Kwon, T.-S., C. M. Lee, and S.-S. Kim. 2014. Northward range shifts in Korean butterflies. Climatic Change 126:163-174. http:// dx.doi.org/10.1007/s10584-014-1212-2

Lin, R.-S., P.-F. Lee, T.-S. Ding, and Y.-T. K. Lin. 2007. Effectiveness of playbacks in censusing the Fairy Pitta (Pitta nympha) during the breeding season in Taiwan. Zoological Studies 46:242-248. [online] URL: http://zoolstud.sinica.edu.tw/Journals/46.2/242. pdf

Lin, R.-S., Y.-J. Lu, T.-J. Tseng, W.-J. Chen, C.-J. Ko, and, C.-H. Yang. 2016. The red list of birds of Taiwan, 2016. Endemic Species Research Institute and Forestry Bureau, Council of Agriculture, Executive Yuan, Nantou, Taiwan. [online] URL: https://www.
researchgate.net/publication/312045198_The_Red_List_of_Birds_of_Taiwan_2016

Majić, A., A. M. T. de Bodonia, Đ. Huber, and N. Bunnefeld. 2011. Dynamics of public attitudes toward bears and the role of bear hunting in Croatia. Biological Conservation 144:3018-3027. http://dx.doi.org/10.1016/j.biocon.2011.09.005

McGregor, R. C. 1907. The birds of Batan, Camiguin, Y'Ami, and Babuyan Claro, islands north of Luzon. Philippine Journal of Science 2A:337-351.

Moritz, C. 1994. Defining 'evolutionarily significant units' for conservation. Trends in Ecology and Evolution 9:373-375. http:// dx.doi.org/10.1016/0169-5347(94)90057-4

Nenzén, H. K., and M. B. Araújo. 2011. Choice of threshold alters projections of species range shifts under climate change. Ecological Modelling 222:3346-3354. http://dx.doi.org/10.1016/j. ecolmodel.2011.07.011

Nuytemans, H. 1998. Notes on Philippine birds: interesting records from northern Luzon and Batan Island. Forktail 14:39-42. [online] URL: http://orientalbirdclub.org/wp-content/uploads/2012/09/ Nuytemans-Philippine.pdf

Oliveros, C., A. T. Peterson, and M. J. C. Villa. 2008. Birds, Babuyan Islands, province of Cagayan, Northern Philippines: new island distribution records. Check List 4:137-141. http://dx. doi.org/10.15560/4.2.137

Peterson, A. T., J. Soberón, R. G. Pearson, R. P. Anderson, E. Martínez-Meyer, M. Nakamura, and M. B. Araújo. 2011. Ecological niches and geographic distributions. Monographs in Population Biology no. 49. Princeton University Press, Princeton, New Jersey, USA.

Phillips, S. 2017. Maxent software for modeling species niches and distributions. [online] URL: http://biodiversityinformatics.amnh. org/open_source/maxent/

Phillips, S. J., R. P. Anderson, and R. E. Schapire. 2006. Maximum entropy modeling of species geographic distributions. Ecological Modelling 190:231-259. http://dx.doi.org/10.1016/j.ecolmodel.2005.03.026

Phillips, S. J., and M. Dudík. 2008. Modeling of species distributions with Maxent: new extensions and a comprehensive evaluation. Ecography 31:161-175. http://dx.doi.org/10.1111/ j.0906-7590.2008.5203.x

Pruett, C. L., A. Ricono, C. Spern, and K. Winker. 2017. Island life and isolation: the population genetics of Pacific Wrens on the North Pacific Rim. Condor 119:131-142. http://dx.doi. org/10.1650/CONDOR-16-183.1

Rayner, M. J., C. J. F. Carraher, M. N. Clout, and M. E. Hauber. 2010. Mitochondrial DNA analysis reveals genetic structure in two New Zealand Cook's Petrel (Pterodroma cookii) populations. Conservation Genetics 11:2073-2077. http://dx.doi.org/10.1007/ s10592-010-0072-1

Reaser, J. K., L. A Meyerson, Q. Cronk, M. De Poorter, L. G. Eldrege, E. Green, M. Kairo, P. Latasi, R. N. Mack, J. Mauremootoo, D. O'Dowd, W. Orapa, S. Sastroutomo, A. Saunders, C. Shine, S. Thrainsson, and L. Vaiutu. 2007. Ecological and socioeconomic impacts of invasive alien species 
in island ecosystems. Environmental Conservation 34:98-111. http://dx.doi.org/10.1017/S0376892907003815

Severinghaus, L. L., T.-S. Ding, W.-H. Fang, W.-H. Lin, M.-C. Tsai, and C.-W. Yen. 2010. The avifauna of Taiwan. [Translated from the Chinese]. Forestry Bureau of Council of Agriculture of Executive Yuan, Taipei, Taiwan.

Severinghaus, L. L., T.-S. Ding, W.-H. Fang, W.-H. Lin, M.-C. Tsai, and C.-W. Yen. 2017. The avifauna of Taiwan. Forestry Bureau, Council of Agriculture, Taipei, Taiwan. [online] URL: http://conservation.forest.gov.tw/0001888

Sutherland, W. J., I. Newton, and R. E. Green, editors. 2004. Bird ecology and conservation: a handbook of techniques. Oxford University Press, Oxford, UK. http://dx.doi.org/10.1093/acprof: oso/9780198520863.001.0001

Veitch, C. R., and M. N. Clout, editors. 2002. Turning the tide: the eradication of invasive species. IUCN Species Specialist Group, Gland, Switzerland and Cambridge, UK.

Walther, B. A., C. Boëte, A. Binot, Y. By, J. Cappelle, J. J. CarriqueMas, M. Chou, N. Furey, S. Kim, C. Lajaunie, S. Lek, P. Méral, M. Neang, B.-H. Tan, C. Walton, and S. Morand. 2016. Biodiversity and health: lessons and recommendations from an interdisciplinary conference to advise Southeast Asian research, society and policy. Infection, Genetics and Evolution 40:29-46. http://dx.doi.org/10.1016/j.meegid.2016.02.003

Walther, B. A., T.-Y. Wu, Y.-H. Chen, R.-S. Lin, and P.-F. Lee. 2011. Using species distribution models to assess the rarity and conservation status of Taiwanese birds. Taiwan Journal of Biodiversity 13:295-322. [online] URL: http://tesri.tesri.gov.tw/ files/tesri_protect/tesri_queen_20120614101857/3.PDF

Warren, D. L., R. E. Glor, and M. Turelli. 2010. ENMTools: a toolbox for comparative studies of environmental niche models. Ecography 33:607-611. http://dx.doi.org/10.1111/j.1600-0587.2009.06142. $\mathrm{x}$

Wilcove, D. S., X. Giam, D. P. Edwards, B. Fisher, and L. P. Koh. 2013. Navjot's nightmare revisited: logging, agriculture, and biodiversity in Southeast Asia. Trends in Ecology and Evolution 28:531-540. http://dx.doi.org/10.1016/j.tree.2013.04.005

Wu, J., and Y. Shi. 2016. Attribution index for changes in migratory bird distributions: the role of climate change over the past 50 years in China. Ecological Informatics 31:147-155. http:// dx.doi.org/10.1016/j.ecoinf.2015.11.013

Wu, T.-Y., B. A. Walther, Y.-H. Chen, R.-S. Lin, and P.-F. Lee. 2014. Reassessment of the conservation status and protected area coverage of Taiwanese birds: how distribution modelling can help species conservation. Bird Conservation International 24:223-238. http://dx.doi.org/10.1017/S0959270913000336 


\section{Appendix 1. Brief assessment of the current conservation status of the Japanese}

Paradise-Flycatcher.

\section{Supplementary Text}

Text A1. Brief assessment of the current conservation status of the Japanese Paradise-Flycatcher.

This brief assessment is based on the information obtained by the fourth and corresponding author (see Methods in main text).

The Japanese Paradise-Flycatcher has been categorized as near-threatened since 1994 because it is suspected to have been in a moderately rapid decline, probably because of habitat degradation and habitat loss on both the breeding and wintering grounds (Higuchi and Morishita 1999, BirdLife International 2015). However, this status assessment is mainly based on its decrease in Japan where it was common on Kyushu, Shikoku, and southern Honshu up to Tokyo's latitude, and scarcer further north, but has decreased during the last 50 years to become uncommon and local except in western Japan (specifically, Kyushu, Shikoku, and Tsushima) where it remains locally common (Brazil 1991, 2013). In addition, this assessment is mainly based on relatively old studies from Japan which detected a steep decline in parts of the Japanese breeding population between the 1970s and 1990s (Hirano 1996, Higuchi and Morishita 1999), including the complete extinction in a forest plot near Higashimatsuyama city, Japan, between 1972 and 1995 (Uchida 1996 cited in Higuchi and Morishita 1999), and population declines detected in Yamaguchi Prefecture between 1973 and 1995 (Yamamoto and Seto 1997) and in Amami Island, Ryukyu, between 1985 and 2001 (Sugimura et al. 2003). According to H. Higuchi (in litt. 2015), no further studies have been published since then to assess the species' current status in Japan, although its status appears unchanged since the 1990s. Furthermore, the species was recorded as a common breeder on Nakano-shima Island, Japan (Higuchi and Morishita 1999) and described as common on Ryukyu Islands (Brazil 1991, Coates et al. 2006). H. Higuchi (in litt. 2015) asserted that the Ryukyu population remains common and stable. 
In Korea, the Ministry of the Environment designated the Japanese Paradise-Flycatcher as an Endangered Bird Species Level II and reported records up to 37 ${ }^{\circ} \mathrm{N}$ between 1997 and 2005 (Kim et al. 2010a). The distribution has been moving northwards with several recently confirmed records over $37^{\circ} \mathrm{N}$ (H. Kim, in litt. 2016). A recent status report published by Birds Korea (2014) categorized the species as an amber species which means it has (1) a global status of near-threatened, and (2) its national status assessed by NIBR $(2011,2012)$ is "vulnerable." This report also stated that the species "is increasingly recorded in the ROK [ $=$ South Korea], with recent breeding confirmed north to at least $35^{\circ} \mathrm{N}$, " and both its historical and recent population trends are increasing. The breeding population was estimated to be between 100 and 999 individuals. However, Kim et al. (2010c) wrote that the species "has rapidly declined due to habitat loss (i.e. deforestation and industrialization)." This apparent contradiction in the assessment of the species' trend is likely due to several factors: (1) increased sampling effort in both intensity and geographic coverage because of (i) increased survey efforts (C.-Y. Choi in litt. 2016) and (ii) the "increased number of birders and bird photographers during [the last] 20 years [which] may be over 100 times more than before" (H. Kim, in litt. 2016); (2) successful reforestation after the Korean War has steadily increased suitable forest habitat in South Korea while North Korea continues to suffer from deforestation (C.-Y. Choi, H. Kim, in litt. 2016); (3) however, locally, detrimental pressures may negatively affect the species. In conclusion, the general impression is that the species trend is stable or slightly increasing while spreading northwards; however, this impression is somewhat clouded by the increased observer density and the lack of reliable long-term data on a national basis. C.-Y. Choi (in litt. 2016) even asserted that "any nationwide assessment on the trend of the species is unreliable and probably biased at this stage."

A 2010 survey of Jeju Island, which is a 1,848 $\mathrm{km}^{2}$ island of the southern tip of Korea, found a total of 124 individuals in evergreen forest between 83 and 1106 meters a. s. 1. (Kim et al. 2010b). Jeju's broad-leaved forests have increased in area and quality, and many parts of them are protected within a national park and thus serve as a stronghold of the species in Korea (C.-Y. Choi, in litt. 2016).

Within the administrative boundaries of Taiwan, T. a. periophtalmica is known to breed exclusively on Lanyu, and its conservation status is given as category 2 "rare and valuable" (Severinghaus et al. 2010, 2017, WCAT 2013, Lin et al. 2016). Fang (2005) estimated the population as fewer than 500 individuals and warned that clearance for agriculture, roads and construction is reducing suitable habitat 
but admitted that "its breeding population in Taiwan is difficult to assess." Brazil (2009) estimated fewer than 100 breeding pairs in Lanyu, but without giving any further details. Lin et al. (2016) listed the species under "Nationally Near-threatened bird taxa in Taiwan."

During the 2009 breeding season (see also main text), preliminary data on the species' phenology was collected (Severinghaus, L. L., and M. L. Bai. 2009. Habitat use and breeding biology of the black paradise flycatcher (in Chinese). Forestry Bureau of Council of Agriculture of Executive Yuan, Taipei, Taiwan. Unpublished Report) which established that the Japanese Paradise-Flycatcher was present on Lanyu from late February until mid-September. After mid-September, T. B. never observed any individuals. However, a few individuals were occasionally observed in some previous years during the winter season by L. L. S. (unpublished data) and a local birdwatcher (G.-Q. Wang). Severinghaus et al. (2017) wrote that after the breeding season "most leave to overwinter somewhere else; only a few remain on Orchid Island for the winter." Therefore, the vast majority of individuals are absent during the winter months.

The Japanese Paradise-Flycatcher breeds on the islands or island groups of the Batanes (namely Batan, Itbayat, Ivuhos islands, and Sabtang) in the very north of the Philippines (Gonzalez et al. 2008), with 91 captures in suitable habitat during a 2006-2007 survey (J.C.T. Gonzalez, in litt. 2016) where it was described as common (Coates et al. 2006) or fairly common (J.C.T. Gonzalez, in litt. 2016).

With only two known breeding populations in Lanyu and Batanes, this subspecies may be threatened because (1) its range is small; and (2) like the other subspecies, it may suffer from the habitat destruction of the wintering grounds.

Besides the incomplete and sometimes contradictory information above, the overall conservation status of the Japanese Paradise-Flycatcher also remains questionable because no reliable global population size estimate exists. The only estimates for breeding populations are the ones given above for Lanyu and in the present study and the very wide-ranging estimates of 100-10,000 breeding pairs for both Japan and Korea (Brazil 2009, BirdLife International 2015). Because of these uncertainties, BirdLife International (2015) conceded that the data quality for this species was poor and recommended that therefore the species "should be carefully monitored." 


\section{LITERATURE CITED}

BirdLife International. 2015. Species factsheet: Terpsiphone atrocaudata. [online] URL: http://www.birdlife.org/datazone/species/factsheet/22707151

Birds Korea. 2014. Status of birds 2014. Birds Korea, Busan, Republic of Korea. [online] URL: http://www.birdskorea.org/Habitats/Yellow-Sea/YSBR/Downloads/Birds-Korea-Status-of-Birds2014.pdf

Brazil, M. 2009. Birds of East Asia: China, Taiwan, Korea, Japan, and Russia. Princeton University Press, Princeton, New Jersey, USA.

Brazil, M. A. 1991. The birds of Japan. Christopher Helm, London, UK.

Brazil, M. A. 2013. The nature of Japan: From dancing cranes to flying fish. Japan Nature Guides, Japan.

Coates, B. J., G. C. L. Dutson, C. E. Filardi, P. Clement, P. A. Gregory, and C. W. Moeliker. 2006. Family Monarchidae (monarch-flycatchers). Pages 244-329 in J. del Hoyo, A. Elliott, and D. Christie, editors. Handbook of the birds of the world. Vol. 11. Old World flycatchers to Old World warblers. Lynx Edicions, Barcelona.

Fang, W.-h. 2005. A guide to threatened birds of Taiwan. Taipei, Taiwan.

Gonzalez, J. C. T., L. E. Afuang, and A. V. Lacaste. 2008. Identifying conservation priorities for terrestrial vertebrate fauna in the Batanes Islands, northern Philippines. Journal of Nature Studies 7:1-8.

Higuchi, H., and E. Morishita. 1999. Population declines of tropical migratory birds in Japan. Actinia 12:51-59.

Hirano, T. 1996. Changes in breeding avifauna during the past 25 years at Tomatsuriyama in Utsunomiya City, central Japan. Strix 14:25-31. 
Kim, C.-H., J.-H. Kang, Y. Lee, D.-W. Kim, J.-H. Suh, and M. Kim. 2010a. Distribution of the endangered birds species in South Korea. Korean Journal of Ornithology 17:67-137.

Kim, Y.-H., W.-B. Kim, and H.-S. Oh. 2010b. The distribution of black paradise flycatcher on Jeju Island and management. Korean Journal of Ornithology 18:141-148.

Kim, Y.-H., H.-S. Oh, Y.-C. Jang, and S.-S. Choi. 2010c. Nest environment selection of black paradise flycatcher (Terpsiphone atrocaudata). Korean Journal of Ornithology 17:11-19.

Lin, R.-S., Y.-J. Lu, C.-H. Yang, T.-J. Tseng, C.-J. Ko, and W.-J. Chen. 2016. The red list of birds of Taiwan, 2016. Endemic Species Research Institute and Forestry Bureau, Council of Agriculture, Executive Yuan, Nantou, Taiwan. [online] URL: https://www.researchgate.net/publication/312045198_The_Red_List_of_Birds_of_Taiwan_2016 NIBR. 2011. Red data book of endangered birds in Korea. Published in Korean (with English summaries). National Institute of Biological Resources, Incheon, Republic of Korea.

NIBR. 2012. Endemic species of Korea. National Institute of Biological Resources, Incheon, Republic of Korea.

Severinghaus, L. L., T.-S. Ding, W.-H. Fang, W.-H. Lin, M.-C. Tsai, and C.-W. Yen. 2010. The avifauna of Taiwan (in Chinese). Forestry Bureau of Council of Agriculture of Executive Yuan, Taipei, Taiwan.

Severinghaus, L. L., T.-S. Ding, W.-H. Fang, W.-H. Lin, M.-C. Tsai, and C.-W. Yen. 2017. The avifauna of Taiwan (in English). Forestry Bureau, Council of Agriculture, Taipei, Taiwan. [online] URL: http://conservation.forest.gov.tw/0001888

Sugimura, K., F. Yamada, and A. Miyamoto. 2003. Population trend, habitat change and conservation of the unique wildlife species on Amami Island, Japan. Global Environmental Research 7:79-89.

Uchida, H. 1996. Black paradise flycatchers declined drastically in Higashimatsuyama city (in Japanese). Yacho 591:13. 
WCAT. 2013. Wildlife Conservation Act of Taiwan. [online] URL:

http://law.coa.gov.tw/GLRSnewsout/EngLawContent.aspx ?Type=E\&id=146

Yamamoto, Y., and N. Seto. 1997. Decrease of summer visiting birds in Yamaguchi Prefecture analyzed from records of regular birding events. Strix 15:15-23. 


\section{Supplementary Tables}

Table A1.1. List of 22 environmental data layers (or variables) used to build distribution models of the Japanese Paradise-Flycatcher. The abbreviations used for the data layers and their data sources are: DTM = digital elevation model; $\mathrm{LCT}=$ land cover type; $\mathrm{NDVI}=$ normalized differenced vegetation index; SI = solar irradiation; std. dev. = standard deviation (for more details, see Methods). Continuous or categorical values for each grid cell were calculated as follows: (1) Means and standard deviations were calculated using only values of the original data source found within each grid cell; (2) percentage coverage was calculated as the percentage of the area of the entire grid cell covered by the respective land cover type; (3) the dominant land cover type of each grid cell was the land-cover type with the highest percentage of coverage within each grid cell. The nine data layers which we used to construct our final models are marked with an asterisk (*); see Table 1. ${ }^{\$}$ This data layer was generated for 1948 and 2006 (see Methods for details).

\begin{tabular}{ccccc}
\hline Number & Data layer & Data source & Type & Calculation of values \\
\hline 1 & NDVI mean* & FORMOSAT-2 & continuous & 1 \\
2 & NDVI std. dev. & FORMOSAT-2 & continuous & 1 \\
3 & elevation mean* & DTM & continuous & 1 \\
4 & elevation std. dev.* & DTM & continuous & 1 \\
5 & $\%$ aspect flat & DTM & continuous & 2 \\
6 & $\%$ aspect north & DTM & continuous & 2 \\
7 & $\%$ aspect south* & DTM & continuous & 2 \\
8 & $\%$ aspect east & DTM & continuous & 2 \\
9 & $\%$ aspect west & DTM & continuous & 2 \\
10 & slope mean & DTM & continuous & 1 \\
11 & slope std. dev. & DTM & continuous & 1 \\
12 & SI mean & DTM & continuous & 1 \\
13 & SI std. dev. & DTM & continuous & 1 \\
14 & $\%$ road & LCT & continuous & 2 \\
15 & $\%$ bare coastal land* & LCT & continuous & 2
\end{tabular}




\begin{tabular}{ccclc}
16 & $\%$ built-over land & LCT & continuous & 2 \\
17 & $\%$ farm/grassland* & LCT & continuous & 2 \\
18 & $\%$ hilltop shrub* & LCT & continuous & 2 \\
19 & $\%$ stunted forest & LCT & continuous & 2 \\
20 & $\%$ tall forest* & LCT & continuous & 2 \\
21 & $\%$ other types & LCT & continuous & 2 \\
22 & dominant land cover type* $\$$ & LCT & categorical & 3 \\
\hline
\end{tabular}


Table A1.2. Mean \pm standard deviation (range in brackets) for all environmental data layers calculated across all grid cells ( $\mathrm{n}=4632$ ), presence grid cells $(\mathrm{n}=120)$ and absence grid cells $(\mathrm{n}=104)$. For abbreviations, see Table A1.1. Not included is the dominant land cover type because it is a categorical variable.

\begin{tabular}{|c|c|c|c|c|}
\hline Variable & Unit & All grid cells & Presence grid cells & Absence grid cells \\
\hline NDVI mean & unitless & $0.65 \pm 0.20(-0.14-0.78)$ & $0.74 \pm 0.03(0.62-0.78)$ & $0.67 \pm 0.10(0.35-0.77)$ \\
\hline NDVI std. dev. & unitless & $0.05 \pm 0.05(0.00-0.33)$ & $0.02 \pm 0.02(0.01-0.14)$ & $0.06 \pm 0.05(0.01-0.21)$ \\
\hline Elevation mean & $\mathrm{m}$ & $173.5 \pm 140.2(0.0-524.4)$ & $171.9 \pm 93.8(15.9-398.5)$ & $133.2 \pm 137.4(3.7-517.0)$ \\
\hline Elevation std. dev. & $\mathrm{m}$ & $11.9 \pm 8.2(0.0-47.5)$ & $13.2 \pm 6.2(2.4-34.8)$ & $10.0 \pm 8.3(0.5-39.6)$ \\
\hline$\%$ aspect flat & $\%$ & $9.4 \pm 20.1(0.0-100.0)$ & $2.7 \pm 5.9(0.0-29.5)$ & $11.3 \pm 19.2(0.0-85.1)$ \\
\hline$\%$ aspect north & $\%$ & $22.8 \pm 28.9(0.0-100.0)$ & $21.3 \pm 27.4(0.0-99.5)$ & $27.4 \pm 27.9(0.0-100.0)$ \\
\hline$\%$ aspect south & $\%$ & $25.1 \pm 31.1(0.0-100.0)$ & $31.0 \pm 32.1(0.0-100.0)$ & $18.8 \pm 29.0(0.0-100.0)$ \\
\hline$\%$ aspect east & $\%$ & $21.7 \pm 29.0(0.0-100.0)$ & $24.4 \pm 29.1(0.0-100.0)$ & $23.9 \pm 28.5(0.0-100.0)$ \\
\hline$\%$ aspect west & $\%$ & $20.8 \pm 28.1(0.0-100.0)$ & $20.6 \pm 26.7(0.0-99.5)$ & $18.6 \pm 27.7(0.0-99.9)$ \\
\hline Slope mean & $\circ$ & $22.3 \pm 12.4(0.0-57.2)$ & $25.7 \pm 8.9(5.3-46.6)$ & $18.7 \pm 12.4(0.9-47.2)$ \\
\hline Slope std. dev. & $\circ$ & $6.5 \pm 3.3(0.0-27.4)$ & $7.2 \pm 2.5(1.7-14.1)$ & $6.8 \pm 3.9(1.7-25.7)$ \\
\hline SI mean & $10^{3} \mathrm{kWh} / \mathrm{m}^{2}$ & $1484.6 \pm 180.1(0.0-1739.9)$ & $1469.6 \pm 147.7(920.8-1676.6)$ & $1495.1 \pm 170.5(838.3-1708.6)$ \\
\hline SI std. dev. & $10^{3} \mathrm{kWh} / \mathrm{m}^{2}$ & $81.6 \pm 58.5(0.0-492.9)$ & $93.5 \pm 52.0(13.3-261.1)$ & $86.6 \pm 73.1(4.6-331.5)$ \\
\hline$\%$ roads & $\%$ & $0.7 \pm 2.2(0.0-19.1)$ & $0.2 \pm 1.3(0.0-11.4)$ & $1.8 \pm 3.2(0.0-14.3)$ \\
\hline$\%$ bare coastal land & $\%$ & $11.2 \pm 29.5(0.0-100.0)$ & $0.0 \pm 0.0\left(\begin{array}{ll}0.0 & 0.0\end{array}\right)$ & $3.8 \pm 15.6(0.0-99.0)$ \\
\hline$\%$ built-over land & $\%$ & $1.6 \pm 9.5(0.0-100.0)$ & $0.1 \pm 0.7(0.0-7.3)$ & $0.5 \pm 3.6(0.0-35.0)$ \\
\hline$\%$ farm/grassland & $\%$ & $12.5 \pm 25.4(0.0-100.0)$ & $5.8 \pm 14.6(0.0-79.6)$ & $27.9 \pm 32.4(0.0-100.0)$ \\
\hline$\%$ hilltop shrub & $\%$ & $7.3 \pm 21.2(0.0-100.0)$ & $4.7 \pm 17.6(0.0-97.0)$ & $6.8 \pm 19.2(0.0-89.0$ \\
\hline$\%$ stunted forest & $\%$ & $56.1 \pm 38.6(0.0-100.0)$ & $63.3 \pm 33.1(0.0-100.0)$ & $52.7 \pm 34.6(0.0-100.0)$ \\
\hline
\end{tabular}


Table A1.3. Model set for modeling the ecological niche of the Japanese Paradise-Flycatcher on Lanyu Island, Taiwan, containing different combinations of the number of background points (BPs), coefficient features (L: linear; Q: quadratic; L + Q: linear + quadratic) and regularization constants $(0.25,0.50$, 0.75, 1.00). AICc, $\triangle \mathrm{AICc}$ and $\mathrm{W} i$ are the Akaike's Information Criterion corrected for small sample sizes, the delta value, the Akaike weight and evidence ratio as defined by Burnham and Anderson (2002). Only models with $\triangle \mathrm{AICc}<2$ marked with an asterisk $(*)$ were included to build our ensemble model (see Methods).

\begin{tabular}{|c|c|c|c|c|}
\hline Model & $\mathrm{AICc}$ & $\Delta \mathrm{AICc}$ & $\mathrm{W} i$ & Evidence ratio \\
\hline \multicolumn{5}{|l|}{$500 \mathrm{BPs}$} \\
\hline $\mathrm{L}(0.25)$ & 399.79 & 8.73 & 0.00207 & 78.78 \\
\hline $\mathrm{L}(0.50)^{*}$ & 392.30 & 1.24 & 0.08768 & 1.86 \\
\hline $\mathrm{L}(0.75)$ & 395.69 & 4.63 & 0.01610 & 10.13 \\
\hline $\mathrm{L}(1.00)^{*}$ & 392.12 & 1.06 & 0.09605 & 1.70 \\
\hline$Q(0.25)$ & 397.78 & 6.72 & 0.00566 & 28.83 \\
\hline $\mathrm{Q}(0.50)$ & 395.69 & 4.63 & 0.01613 & 10.11 \\
\hline $\mathrm{Q}(0.75)$ & 414.51 & 23.45 & 0.000001 & 123382 \\
\hline $\mathrm{Q}(1.00)$ & 403.64 & 12.58 & 0.00030 & 540.23 \\
\hline $\mathrm{L}+\mathrm{Q}(0.25)$ & 396.27 & 5.21 & 0.01203 & 13.55 \\
\hline $\mathrm{L}+\mathrm{Q}(0.50)$ & 397.43 & 6.37 & 0.00674 & 24.21 \\
\hline $\mathrm{L}+\mathrm{Q}(0.75)$ & 400.51 & 9.45 & 0.00145 & 112.64 \\
\hline $\mathrm{L}+\mathrm{Q}(1.00)$ & 396.48 & 5.42 & 0.01083 & 15.06 \\
\hline \multicolumn{5}{|l|}{$1000 \mathrm{BPs}$} \\
\hline $\mathrm{L}(0.25)$ & 401.11 & 10.05 & 0.00107 & 151.98 \\
\hline
\end{tabular}




$\begin{array}{lllll}\mathrm{L}(0.50)^{*} & 391.63 & 0.57 & 0.12246 & 1.33 \\ \mathrm{~L}(0.75) & 399.63 & 8.57 & 0.00224 & 72.67 \\ \mathrm{~L}(1.00) & 402.13 & 11.07 & 0.00064 & 254.04 \\ \mathrm{Q}(0.25) & 418.43 & 27.37 & 0.0000002 & 875465.30 \\ \mathrm{Q}(0.50) & 407.24 & 16.18 & 0.00005 & 3259.27 \\ \mathrm{Q}(0.75) & 409.94 & 18.88 & 0.00001 & 12598.76 \\ \mathrm{Q}(1.00) & 393.56 & 2.50 & 0.04663 & 3.50 \\ \mathrm{~L}+\mathrm{Q}(0.25) & 400.86 & 9.80 & 0.00122 & 134.14 \\ \mathrm{~L}+\mathrm{Q}(0.50) & 393.20 & 2.14 & 0.05600 & 2.91 \\ \mathrm{~L}+\mathrm{Q}(0.75) & 395.01 & 3.95 & 0.02262 & 7.21 \\ \mathrm{~L}+\mathrm{Q}(1.00) & 393.39 & 2.33 & 0.05080 & 3.21\end{array}$

\section{BPs}

$\begin{array}{lllll}\text { L }(0.25) & 405.62 & 14.56 & 0.00011 & 1451.64 \\ \text { L }(0.50) & 399.76 & 8.70 & 0.00210 & 77.58 \\ \text { L }(0.75) & 395.70 & 4.64 & 0.01603 & 10.17 \\ \text { L }(1.00) & 398.52 & 7.46 & 0.00392 & 41.60 \\ \text { Q }(0.25) & 394.44 & 3.38 & 0.03014 & 5.41 \\ \text { Q }(0.50) & 403.48 & 12.42 & 0.00033 & 498.29 \\ \text { Q }(0.75) & 396.17 & 5.11 & 0.01265 & 12.89 \\ \text { Q }(1.00) & 393.11 & 2.05 & 0.05840 & 2.79 \\ \text { L+Q }(0.25) & 400.24 & 9.18 & 0.00165 & 98.69 \\ \text { L+Q }(0.50) & 399.45 & 8.39 & 0.00245 & 66.51 \\ \text { L+Q }(0.75) & 411.87 & 20.81 & 0.000005 & 33086.25\end{array}$




$\begin{array}{lllll}\text { L+Q (1.00** } & 391.06 & 0.00 & 0.16309 & 1.00 \\ & & & & \\ 5000 \text { BPs } & & & & 215.29 \\ \text { L }(0.25) & 401.80 & 10.74 & 0.00076 & 115380.70 \\ \text { L }(0.50) & 414.37 & 23.31 & 0.000001 & 4.22 \\ \text { L }(0.75) & 393.94 & 2.88 & 0.03864 & 21681906.00 \\ \text { L (1.00) } & 424.84 & 33.78 & 0.00000 & 7.24 \\ \text { Q }(0.25) & 395.02 & 3.96 & 0.02254 & 423.26 \\ \text { Q (0.50) } & 403.16 & 12.10 & 0.00039 & 7454.00 \\ \text { Q (0.75) } & 408.89 & 17.83 & 0.00002 & 2.49 \\ \text { Q (1.00)* } & 392.89 & 1.83 & 0.06540 & 163.45 \\ \text { L+Q (0.25) } & 401.25 & 10.19 & 0.00100 & 9.24 \\ \text { L+Q (0.50) } & 395.51 & 4.45 & 0.01765 & 41.24 \\ \text { L+Q (0.75) } & 398.50 & 7.44 & 0.00395 & 380024.60 \\ \text { L+Q (1.00) } & 416.76 & 25.70 & 0.0000004 & \end{array}$




\section{Supplementary figures}

Fig. A1.1. Gridded maps of the important environmental data layers of Lanyu used in the distribution modelling of the Japanese Paradise-Flycatcher. This map depicts elevation mean; the values (cf. Table A1.2) are depicted in two colours from lowest (blue) to highest (red) in 10 equal intervals, and the $100 \mathrm{~m}$ $\mathrm{x} 100 \mathrm{~m}$ grid cells are bounded by grey lines.

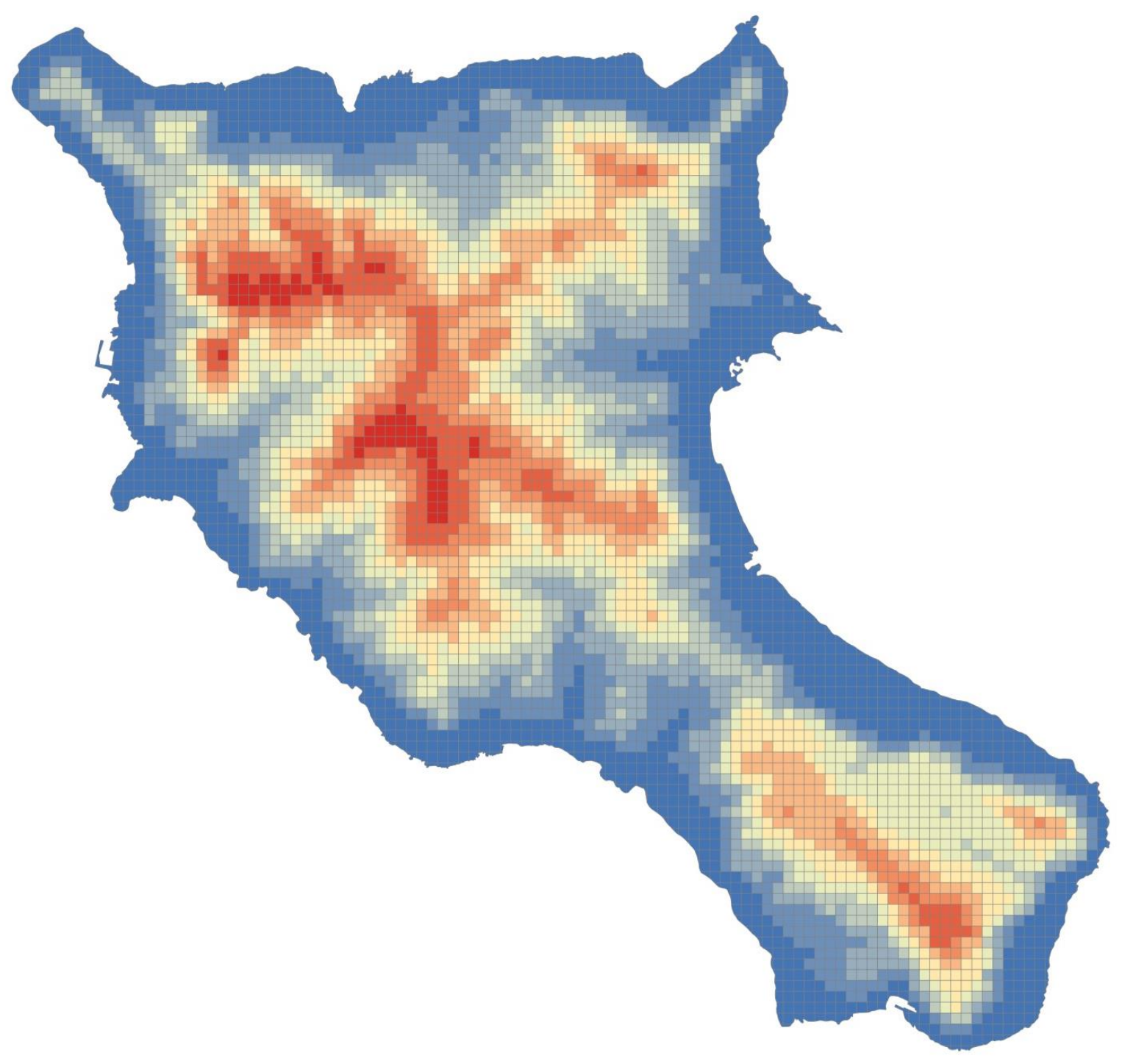


Fig. A1.2. Gridded maps of the important environmental data layers of Lanyu used in the distribution modelling of the Japanese Paradise-Flycatcher. This map depicts NDVI mean; the values (cf. Table A1.2) are depicted in two colours from lowest (blue) to highest (red) in 10 equal intervals, and the $100 \mathrm{~m}$ $\mathrm{x} 100 \mathrm{~m}$ grid cells are bounded by grey lines.

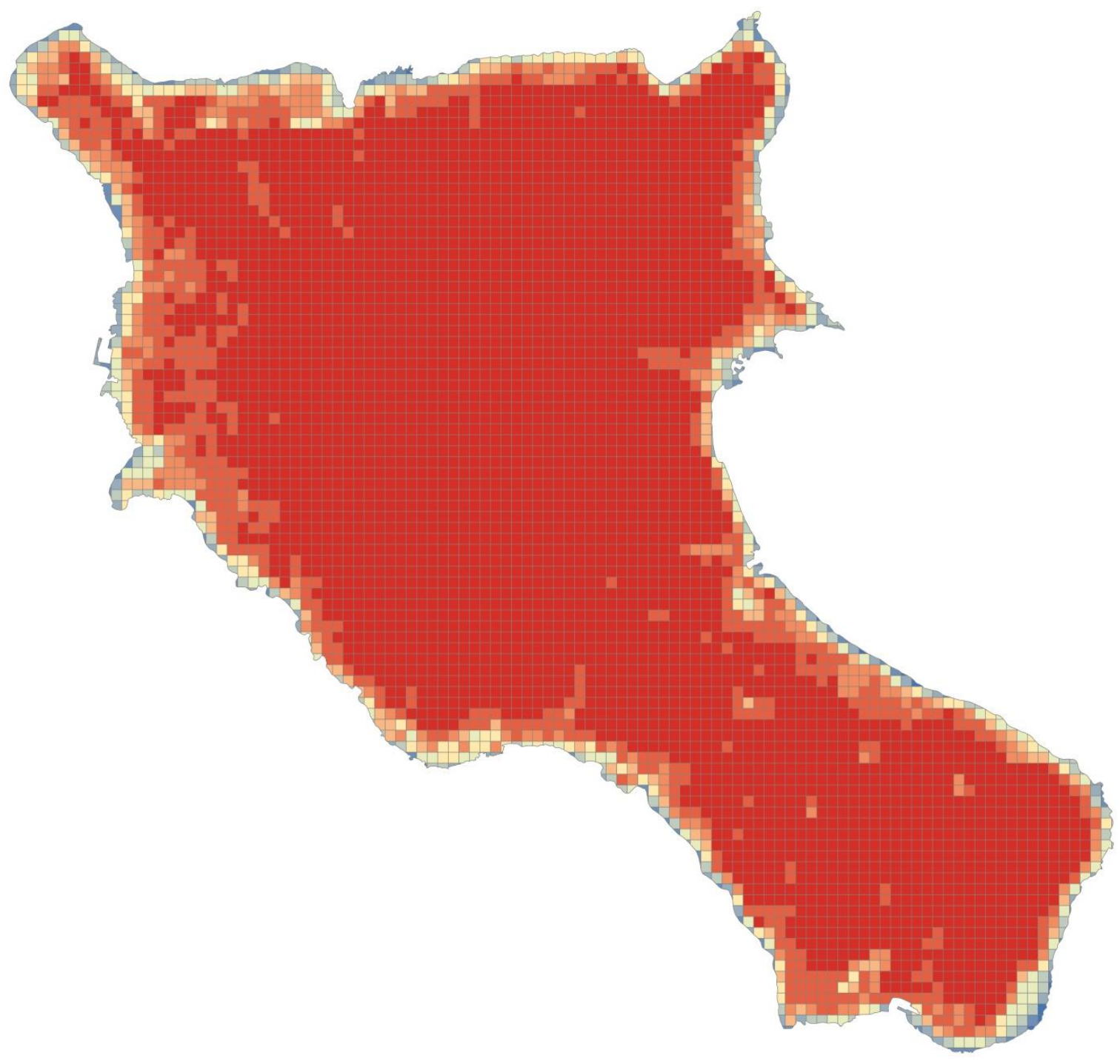


Fig. A1.3. Gridded maps of the important environmental data layers of Lanyu used in the distribution modelling of the Japanese Paradise-Flycatcher. This map depicts \% tall forest; the values (cf. Table A1.2) are depicted in two colours from lowest (blue) to highest (red) in 10 equal intervals, and the $100 \mathrm{~m}$ $\mathrm{x} 100 \mathrm{~m}$ grid cells are bounded by grey lines.

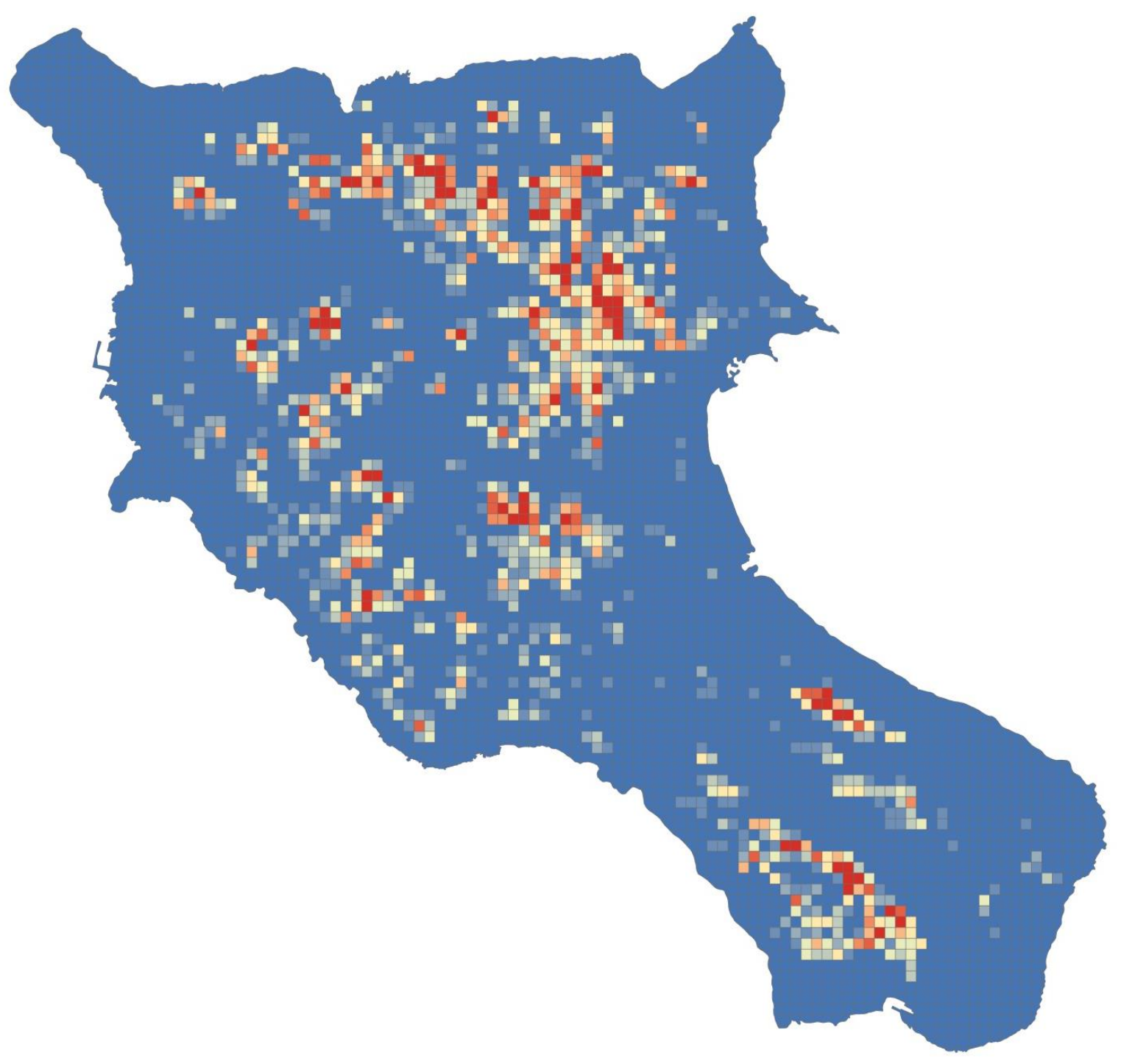


Fig. A1.4. Gridded maps of the important environmental data layers of Lanyu used in the distribution modelling of the Japanese Paradise-Flycatcher. This map depicts dominant land cover type: the colours refer to roads (black), bare coastal lands (greenish brown), other built-over land (yellow), farmland or grassland (grey), hilltop shrub (greenish yellow), stunted forest (orange beige), and tall forest (light beige). The category 'other types' is not depicted because it covered a very small area (Table A1.2).

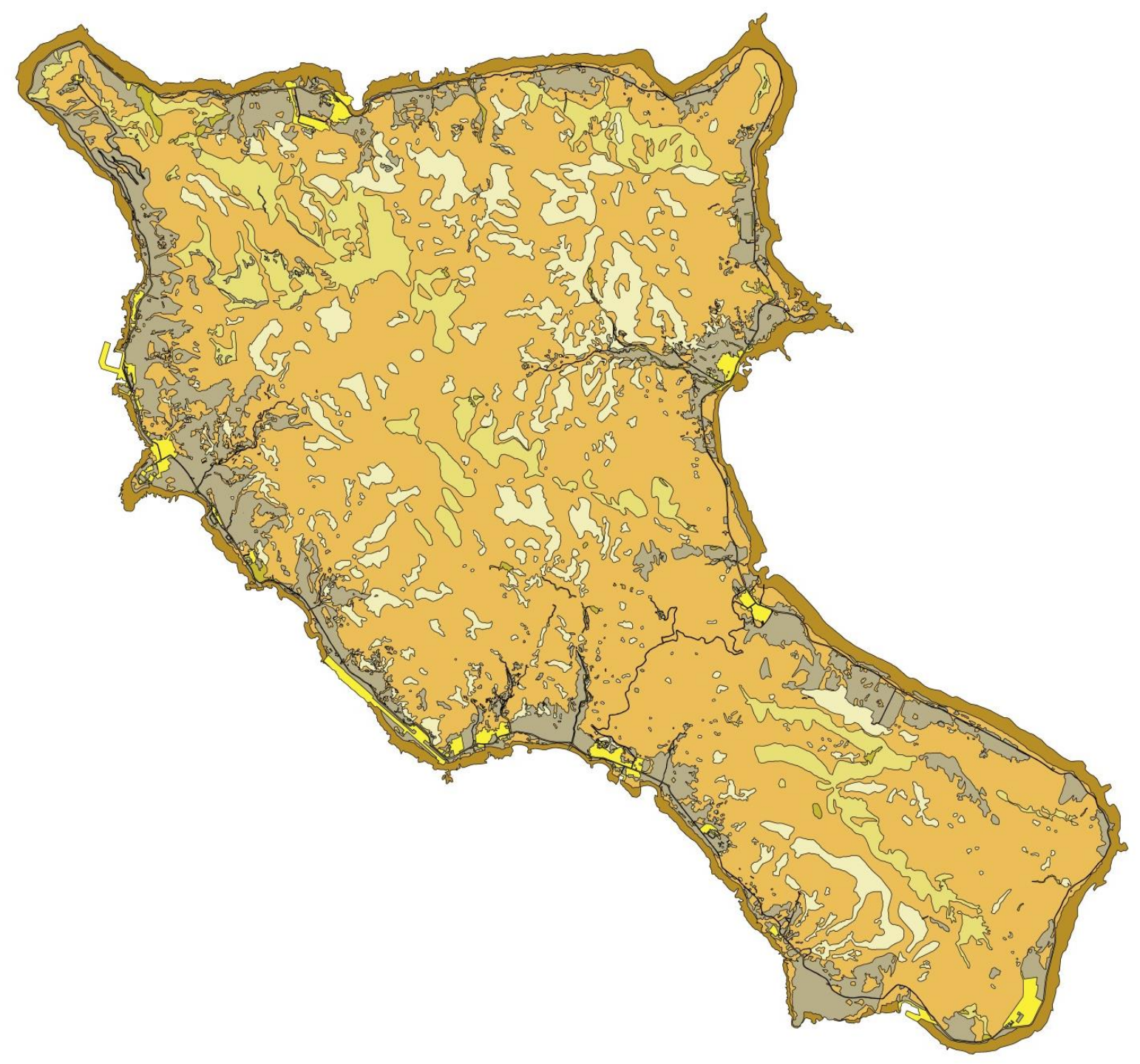


Fig. A1.5. Frequency distribution depicting the variation in percentage of stunted forest associated with the 120 presence grid cells for the Japanese Paradise-Flycatcher. Note that the right peak in this Figure largely corresponds to the left peak in Fig. 3B.

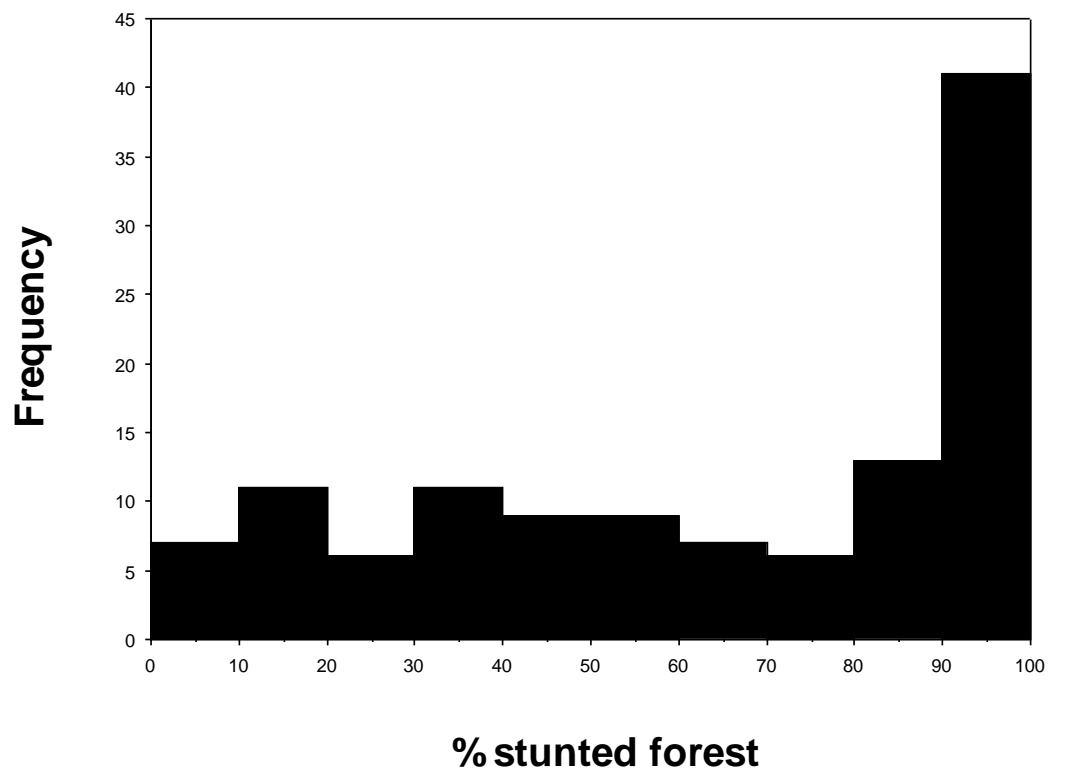


Fig. A1.6. (A) Forest present in 2006 (dark green) and forest lost between 1948 and 2006 (yellow). Grey areas are non-forest areas (i.e., not categorized as either hilltop shrub, stunted forest, or tall forest).

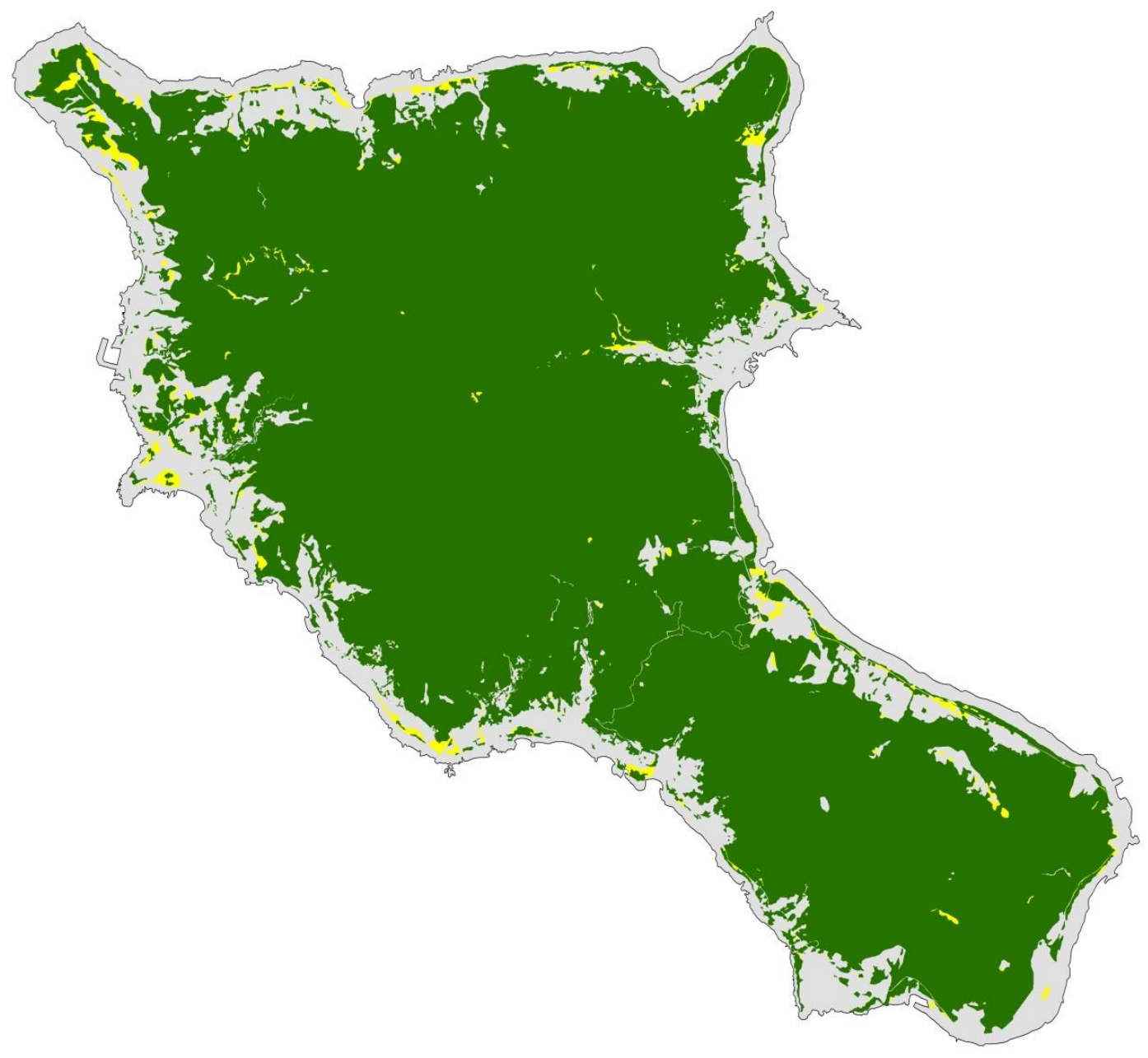


Fig. A1.7. Forest present in 1948 (dark green) and forest gained between 1948 and 2006 (yellow). Grey areas are non-forest areas (i.e., not categorized as either hilltop shrub, stunted forest, or tall forest).

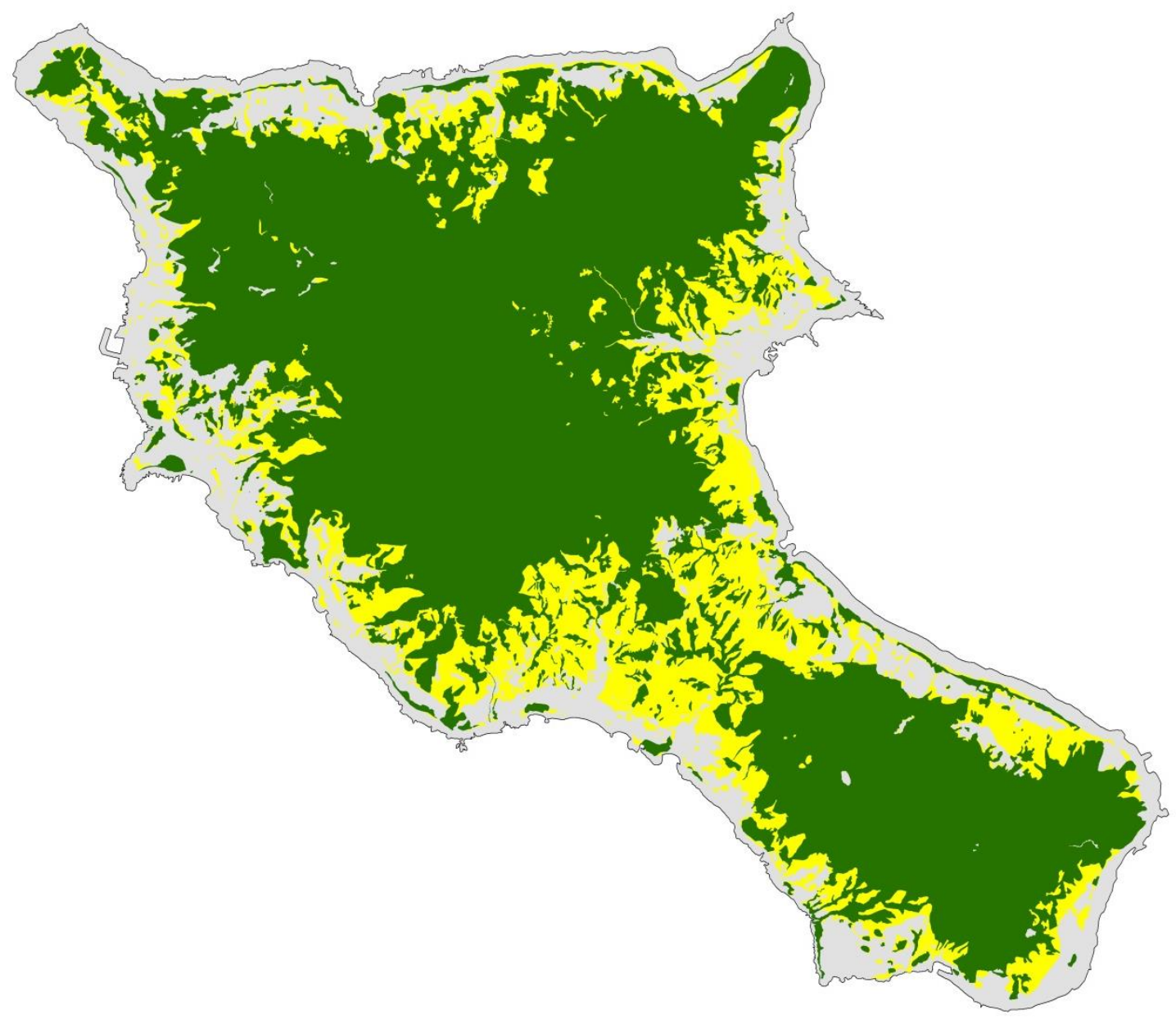


Fig. A1.8. Binary distribution model of Japanese Paradise-Flycatcher as depicted in Fig. 5 of main text, but here, the predicted presence grid cells are overlaid with the forest areas gained between 1948 to 2006 (yellow areas in Fig. A1.7).

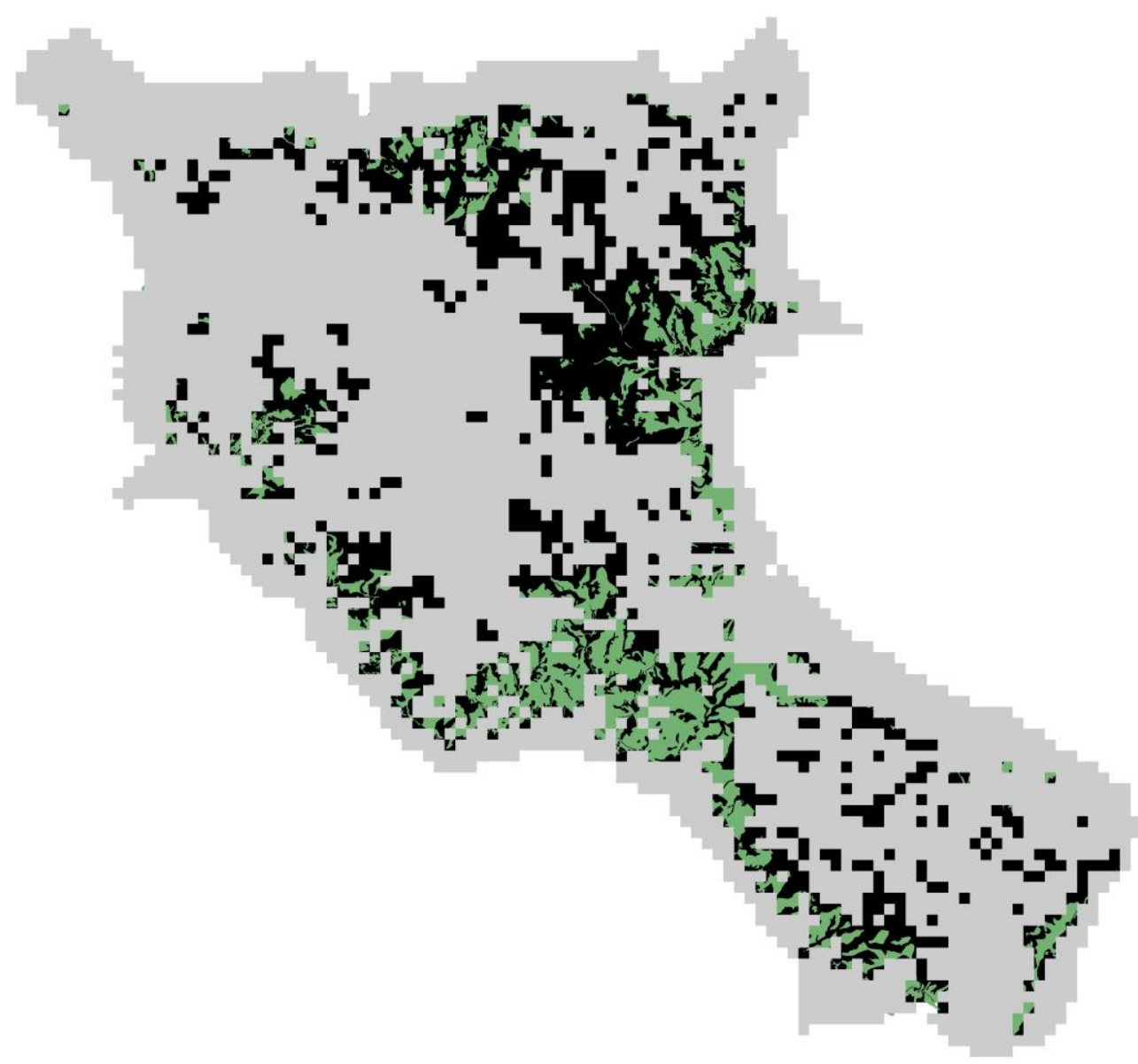

